\title{
Synthetic approach to microsclerodermins: construction of three building blocks
}

\author{
Takayuki Shioiri, ${ }^{*},{ }^{1}$ Shigekazu Sasaki, ${ }^{2}$ and Yasumasa Hamada ${ }^{3}$ \\ ${ }^{1}$ Graduate School of Environmental and Human Sciences, Meijo University, Shiogamaguchi, \\ Tempaku, Nagoya 468-8502, Japan \\ ${ }^{2}$ Graduate School of Pharmaceutical Sciences, Nagoya City University, Tanabe-dori, Mizuho-ku, \\ Nagoya 467-8603, Japan \\ ${ }^{3}$ Graduate School of Pharmaceutical Sciences, Chiba University, Yayoi-cho, Inage-ku, Chiba \\ 263-8522, Japan \\ E-mail: shioiri@ccmfs.meijo-u.ac.jp
}

Dedicated to Professor Zhi-Tang Huang on the occasion of his $75^{\text {th }}$ birthday

(received 31 Dec 02; accepted 29 Apr 03; published on the web 08 May 03)

\begin{abstract}
As an approach to the construction of microsclerodermins (1), the three building blocks 2, 3, and 4 were efficiently prepared from the carboxylic acids $\mathbf{6 , 1 6}$, and $\mathbf{2 8 .}$
\end{abstract}

Keywords: Microsclerodermin, asymmetric alkylation, 2-hydroxy-3-pinanone, amino acid

\section{Introduction}

Microsclerodermins have been isolated from the lithistid marine sponge Microscleroderma sp. by Faulkner and co-workers. ${ }^{1}$ They are a family of complex cyclic peptides that display potent anti-fungal and anti-proliferative activities. One of the representative peptides are microsclerodermins A and B whose structures have been determined to be 1a and 1b, respectively, as shown in Fig. 1. Our continuing interests in the synthesis of biologically active aquatic natural peptides $^{2}$ led to synthesize micro-sclerodermins. Toward this end, we have already accomplished the synthesis of four requisite building blocks: ${ }^{3}$ the tryptophan derivative $2{ }^{3 \mathrm{~d}}$ the 
hydroxypyrrolidinone equivalent $3,^{3 \mathrm{~d}}$ 4-amino-3-hydroxybutanoic acid (GABOB) derivative 4 , $^{3 \mathrm{~d}}$ and AMMTD 5, ${ }^{3 \mathrm{a}-\mathrm{c}, \mathrm{e}}$ shown in Fig. 1. We now report the details of the synthesis of $\mathbf{2 - 4} .^{3 \mathrm{~d}}$

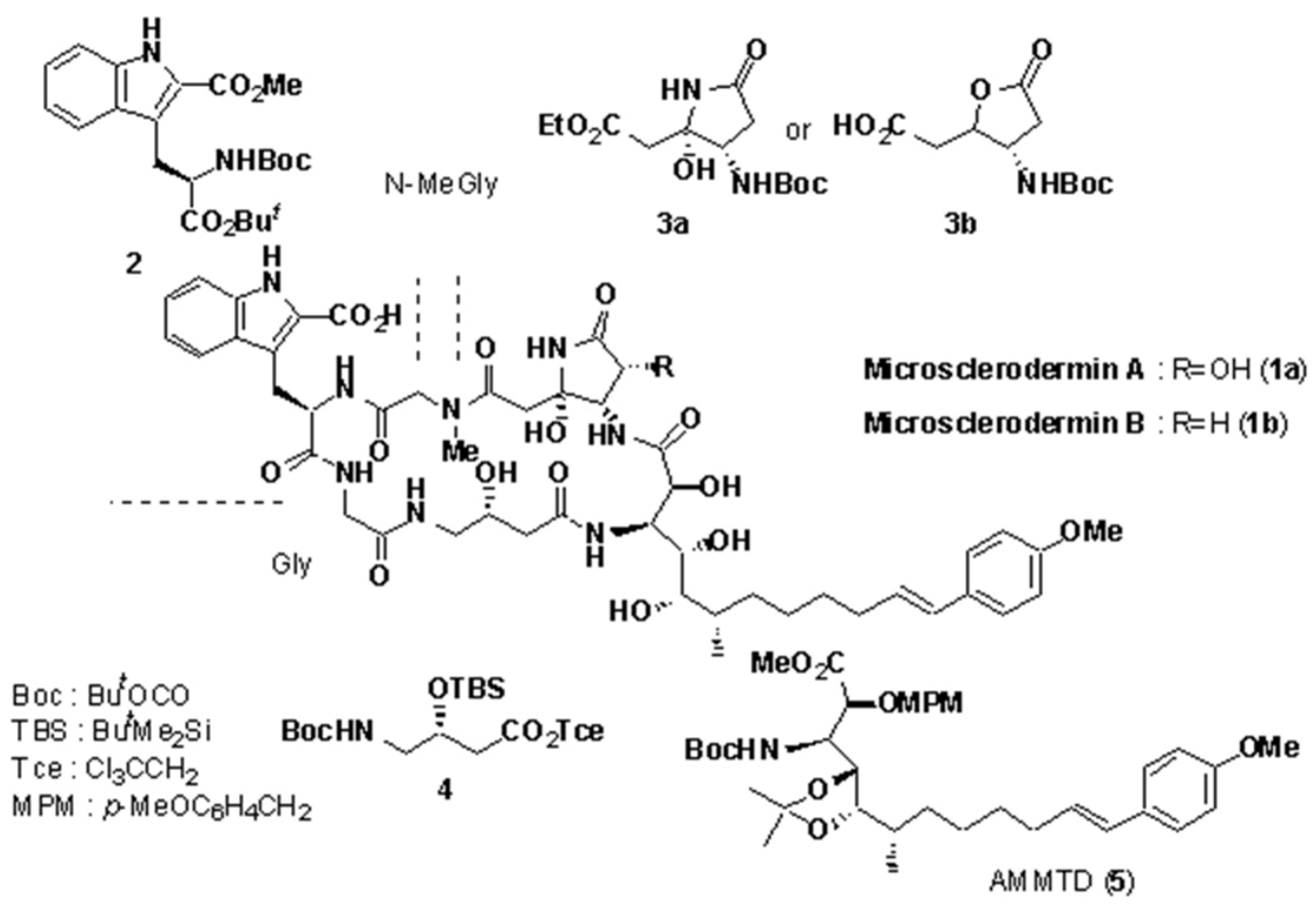

Figure 1

\section{Results and Discussion}

We first synthesized the tryptophan derivative 2 . We have already developed ${ }^{4}$ the method for the asymmetric synthesis of $\boldsymbol{\alpha}$-amino acids by alkylation of the imine $\mathbf{1 0}$ derived from glycine ester and optically active 2-hydroxy-3-pinanone (HyPN, 9). The alkylating agent 8 to carry out this method was prepared from 2-indolecarboxylic acid (6) by esterification with iodomethane, Mannich reaction, and then quaternization, as shown in Scheme 1. The corresponding bromo derivative was also prepared, but it was found to be labile and the chemical yield was variable. The imine 10 derived from (-)- HyPN (9) ${ }^{4 a, b}$ was lithiated with lithium diisopropylamide (LDA) and the resulting enolate was alkylated with $\mathbf{8}$ to give the alkylated imine 11, which was directly treated under weak acidic conditions to remove the chiral auxiliary 9. The resulting amine was converted to the corresponding tert-butoxycarbonyl (Boc) derivative 2 with $\mathrm{Boc}_{2} \mathrm{O}$. The enantiomeric excess of 2 was $87 \%$, and it raised to $91 \%$ by recrystalization. 

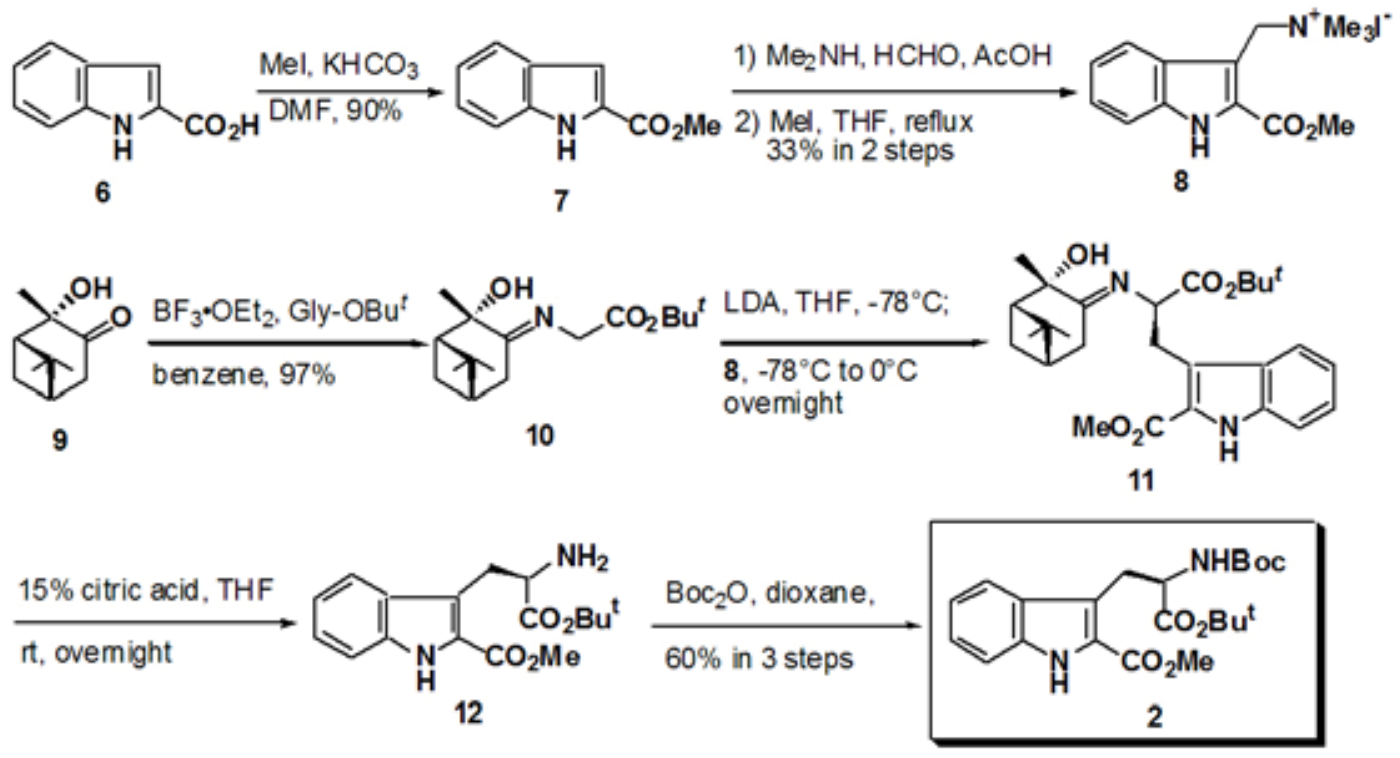

\section{Scheme 1}

The absolute configuration of the tryptophan derivative 2 should be $(R),{ }^{4}$ but it was further unambiguously confirmed by transformation to the known homoserine derivative 15, as shown in Scheme 2. Thus the tryptophan derivative 2 with $87 \%$ ee was oxidized with ruthenium tetroxide to give the aspartic acid derivative $\mathbf{1 3}$ which was purified as the methyl ester 14. Although the compound 14 was known, ${ }^{5}$ its specific rotation was not reported. Therefore, the compound 14 was further transformed to the homoserine derivative 15 in three steps, shown in Scheme 2. The homoserine derivative 15 thus obtained was completely identical with 15 derived from (S)-aspartic acid according to the known method, ${ }^{6}$ but the sign of their specific rotations were opposite to each other: $[\alpha]_{\mathrm{D}}{ }^{25}+32.3$ (c 1.09,EtOH) for $\mathbf{1 5}$ from 2, +37.1 (calcd. for $\mathbf{1 5}$ with $100 \%$ ee), reported ${ }^{6}$ $[\alpha]_{\mathrm{D}}{ }^{25}-37.5$ (c 1, EtOH). These results clearly indicate that the absolute configuration of the tryptophan derivative 2 is $(R)$, as expected. 

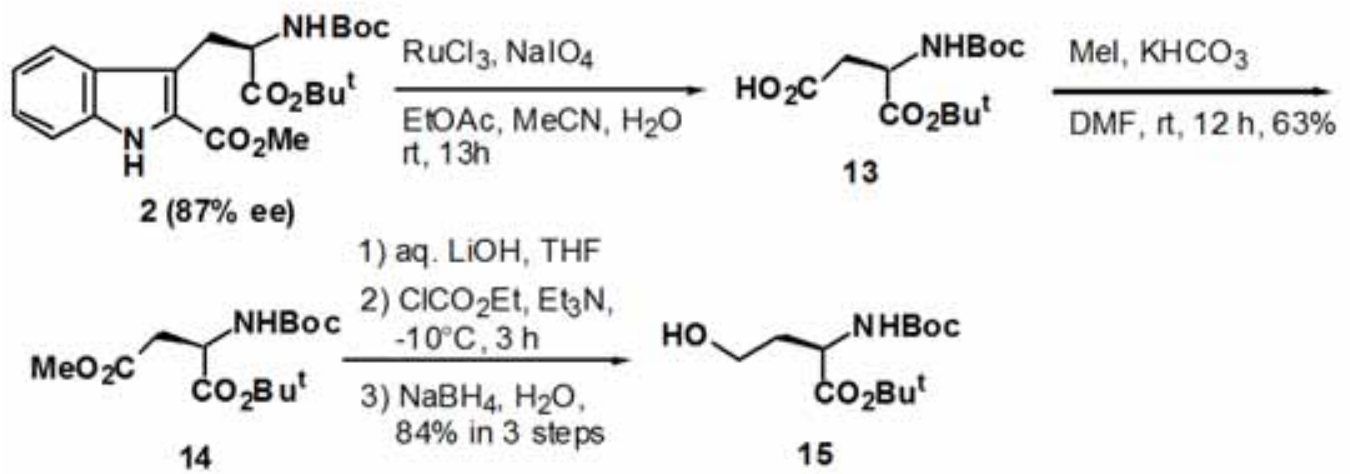

\section{Scheme 2}

The requisite pyrrolidinone derivative 3a was prepared from $N$-Boc-(S)-aspartic acid 4-benzyl ester (16), as shown in Scheme 3. Homologation of $\mathbf{1 6}$ was achieved by treatment with 1,1'-carbonyldiimidazole (CDI) and then the magnesium salt of malonic acid half ester to give the $\beta$-keto ester 17. After catalytic hydrogenolytic removal of the benzyl function, the resulting acid $\mathbf{1 8}$ was treated with ethyl chlorocarbonate-triethylamine and then aqueous ammonia. The products were revealed to be a diastereoisomeric mixture of the cyclic hemiaminals 3a and epi-3a in a ratio of $3: 1^{8}$

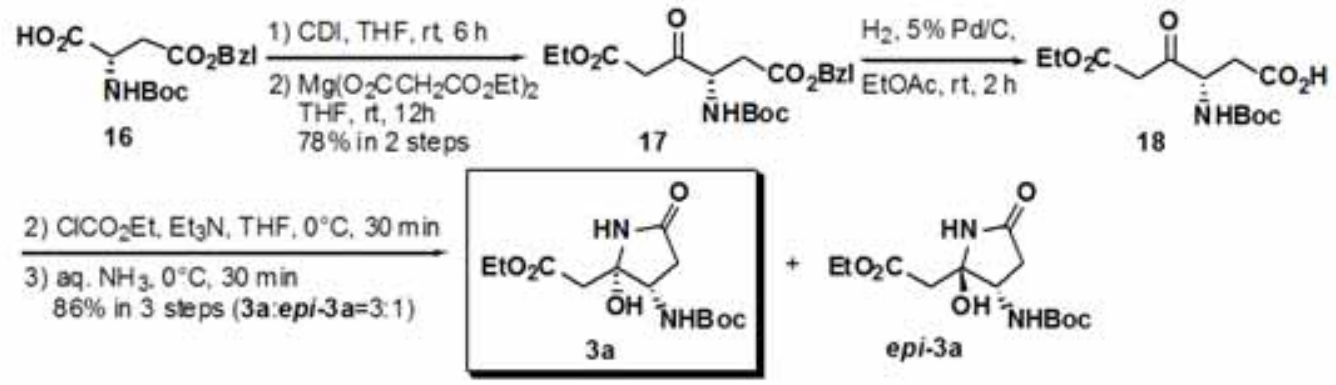

\section{Scheme 3}

The hemiaminal 3a easily underwent the dehydration under both acidic and basic conditions to give thea, $\beta$-unsaturated ester 19, shown in Scheme 4. 


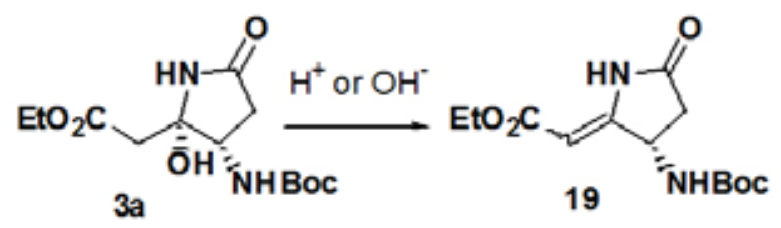

\section{Scheme 4}

These results suggest that the synthesis of microsclerodermins could proceed via they-lactone 21, which will give the keto-amide 20b, equivalent to the hemiaminal 20a, by alkaline hydrolysis, oxidation of the hydroxyl group, and amidation, as shown in Scheme 5.

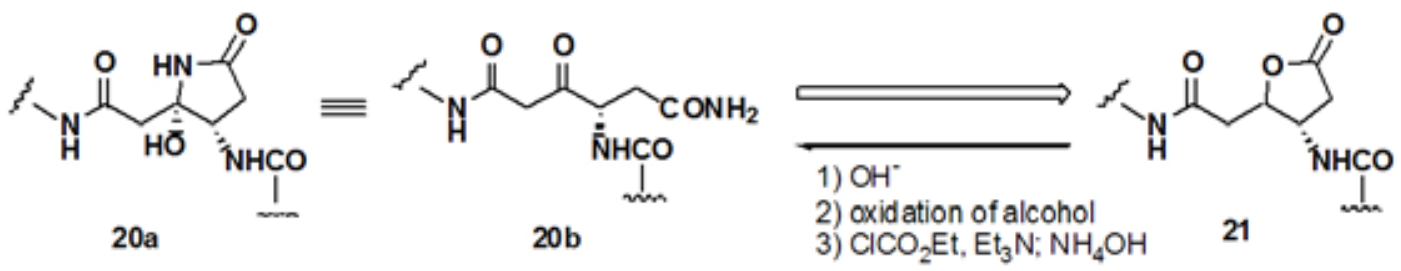

\section{Scheme 5}

Thus, the $\mathrm{Y}$-lactone trimethylsilylethyl (TMSE) ester $\mathbf{2 4}$ was prepared from $\mathbf{1 6}$ by transformation to the imidazolide, homologation with TMSE acetate, ${ }^{9}$ catalytic removal of the benzyl function, reduction with sodium borohydride, and lactonization with 1-ethyl-3-(3-dimethylaminopropyl)-carbodiimide (EDC), as shown in Scheme 6. Attempted removal of the TMSE group with tetrabutylammonium fluoride (TBAF) did not give the $Y$-lactone $\mathbf{3 b}$, but resulted in the formation of the $\alpha, \beta$-unsaturated dicarboxylic acid $25{ }^{10}$

To prepare $\mathbf{3 b}$ in more efficient way, the $\beta$-keto ester $\mathbf{1 7}$ was first transformed to the hydroxy dicarboxylic acid 26, which underwent the lactonization with EDC to give 3b, as shown in Scheme 6. The lactone $\mathbf{3 b}$ was fully characterized by its transformation to the sarcosine derivative $\mathbf{2 7}$. Thus, we could succeed in the efficient synthesis of $\mathbf{3 b}$ in shorter steps. 

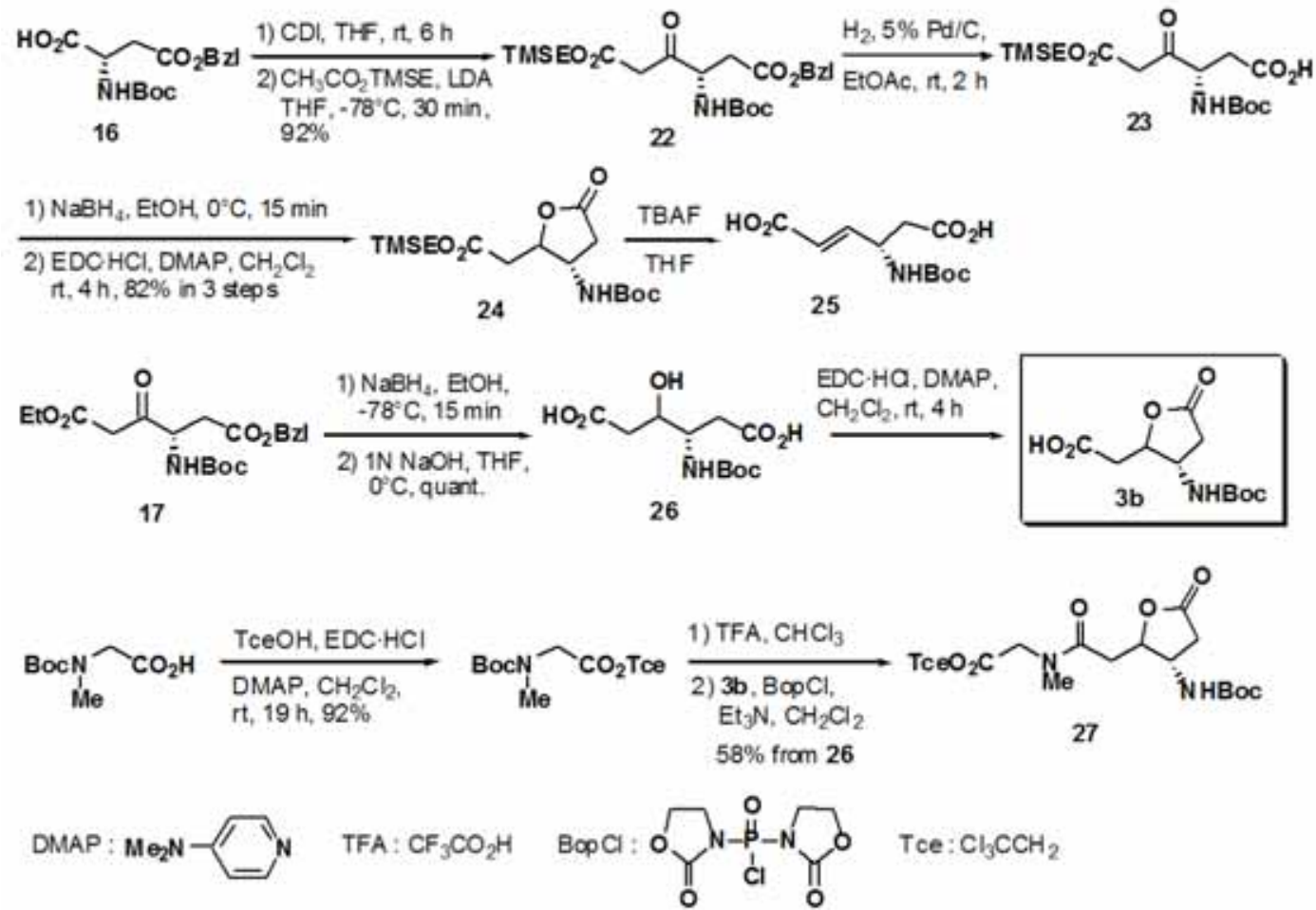

\section{Scheme 6}

Finally, the synthesis of the required GABOB derivative 4 started from dimethyl $(R)$-malate, which was regioselectively reduced according to the known method, ${ }^{11}$ as shown in Scheme 7 . The resulting diol 29 was converted to the hydroxy azide 31 via the tosylate $\mathbf{3 0}$. Catalytic hydrogenation of 31 in the presence of $\mathrm{Boc}_{2} \mathrm{O}^{12}$ afforded the Boc derivative 32, whose methyl ester function was replaced with the trichloroethyl (Tce) one. The Tce ester $\mathbf{3 3}$ was finally converted to the required corresponding tert-butyldimethylsilyl (TBS) derivative 4.

Thus we have succeeded in the efficient synthesis of the required building blocks 2-4 for the construction of microsclerodermins. The methods utilized here will have broad applicability to the synthesis of the other natural products. 

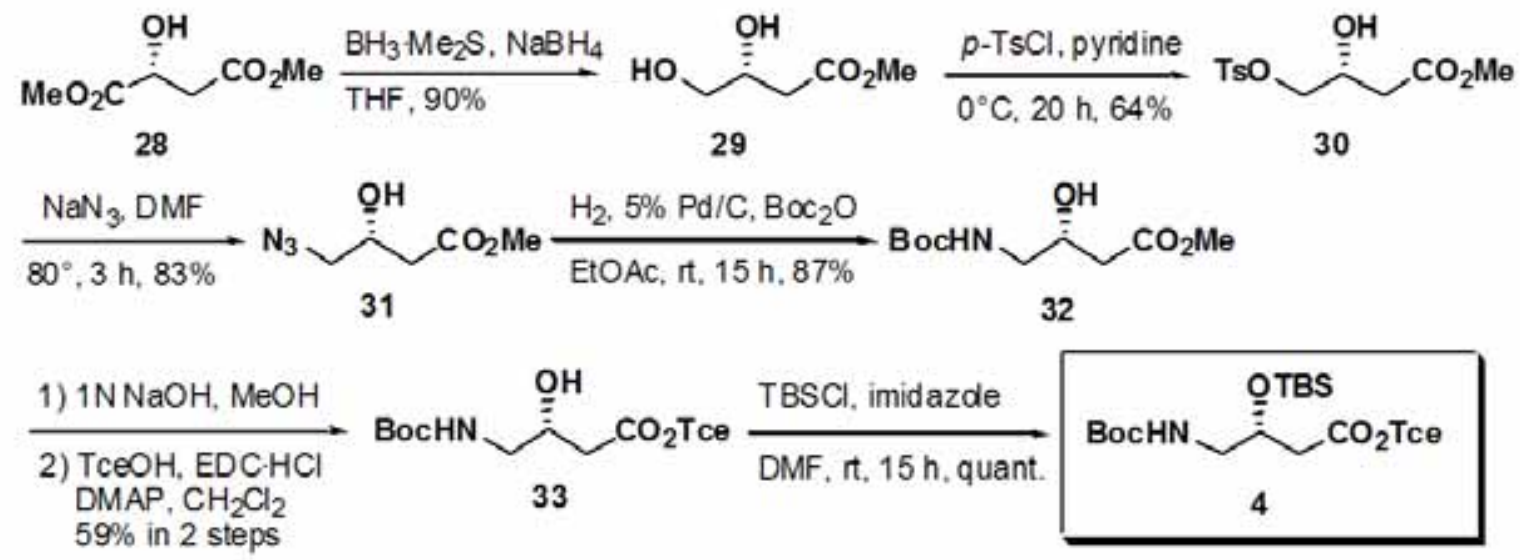

\section{Scheme 7}

\section{Experimental Section}

General Procedures. Melting points were measured with a YAMATO MP-21 or YANAGIMOTO melting point apparatus (hot plate) and are uncorrected. Infrared spectra were recorded on a SHIMADZU FT IR-8100 spectrometer. Optical rotations were measured on a JASCO DIP-140 or DIP-1000 digital polarimeter with a sodium lump ( $\lambda=589 \mathrm{~nm}$, D Line) and are recorded as follows: $[\alpha]_{\mathrm{D}}^{\mathrm{T}}$ (c g/100 ml, solvent).

${ }^{1} \mathrm{H}$ NMR spectra were recorded on a JEOL EX-270 (270 MHz) spectrometer. Chemical shifts are recorded in ppm from tetramethylsilane as the internal standard. Data are recorded as follows: chemical shift, integration, multiplicity $(\mathrm{s}=$ singlet, $\mathrm{d}=$ doublet, $\mathrm{t}=$ triplet, $\mathrm{q}=$ quartet, $\mathrm{br}=$ broad, $\mathrm{m}=$ multiplet), coupling constants $(\mathrm{Hz})$, and assignment. ${ }^{13} \mathrm{C}$ NMR spectra were recorded on a JEOL EX-270 (67.8 MHz) spectrometer with complete proton decoupling. Chemical shifts are recorded in ppm from tetramethylsilane with the solvent as the internal standard (deuterochloroform: $\delta 77.0 \mathrm{ppm}$ ). Mass spectra were obtained on a JEOL LMS-DX 300 spectrometer. Column chromatography was performed with silica gel BW-820MH or BW-200 (Fuji Davison Co.).

Solvents for extraction and chromatography were reagent grade. Tetrahydrofuran (THF) and benzene were distilled from sodium/benzophenone ketyl. Diethyl ether $\left(\mathrm{Et}_{2} \mathrm{O}\right)$ was distilled from lithium aluminum hydride $\left(\mathrm{LiAlH}_{4}\right)$. Dichloromethane $\left(\mathrm{CH}_{2} \mathrm{Cl}_{2}\right)$ was distilled from calcium hydride. Methanol (MeOH), ethanol (EtOH), and hexamethylphosphoric triamide (HMPA) were distilled from calcium hydride and stored over 4 molecular sieves. Diisopropylamine was distilled from 
calcium hydride and stored over sodium hydroxide. $N, N$-Dimethylformamide (DMF) was dried over 4 molecular sieves. Triethylamine was dried over sodium hydroxide. All other commercially available reagents were used as received.

Methyl indole-2-carboxylate (7). To a stirred solution of indole-2-carboxylic acid (6) (16.16 g, 100 mmol) in DMF (200 ml) was added KHCO3 $(11.01 \mathrm{~g}, 110 \mathrm{mmol})$ and MeI (6.82 ml, $110 \mathrm{mmol})$ at $0^{\circ} \mathrm{C}$. The mixture was stirred for $18 \mathrm{~h}$ at room temperature. After dilution with ether (600 ml), the mixture was washed with water ( $200 \mathrm{ml} \times 2)$ and $1 \mathrm{M}$ aqueous $\mathrm{KHSO}_{4}(200 \mathrm{ml} \times 2)$, aqueous saturated $\mathrm{NaHCO}_{3}(200 \mathrm{ml})$, saturated brine (200 ml), dried over MgSO 4 , filtered, and concentrated in vacuo. The crude solid was purified by recrystallization (hexane/EtOAc) to give 7 (15.68 g, 90\%) as colorless needles: $\mathrm{mp} 149-151^{\circ} \mathrm{C}$ (hexane/EtOAc); IR $v_{\max }\left(\mathrm{CHCl}_{3}\right) \mathrm{cm}^{-1} 3021,1703,1215$, 756; ${ }^{1} \mathrm{H}-\mathrm{NMR}\left(\mathrm{CDCl}_{3}\right) \delta 3.95\left(3 \mathrm{H}, \mathrm{s}, \mathrm{CO}_{2} \mathrm{Me}\right)$ 7.13-7.44 $(4 \mathrm{H}, \mathrm{m}, \mathrm{Ar}-\mathrm{H}) 7.70(1 \mathrm{H}, \mathrm{d}, J=8.0 \mathrm{~Hz}$, indole-8-H) $8.88(1 \mathrm{H}, \mathrm{br}, \mathrm{NH})$; ${ }^{13} \mathrm{C}-\mathrm{NMR}\left(\mathrm{CDCl}_{3}\right) \delta 51.98\left(\mathrm{CH}_{3}\right) 108.76(\mathrm{CH}, \mathrm{Ar}) 111.91(\mathrm{CH}$, Ar) $120.73(\mathrm{CH}, \mathrm{Ar}) 122.55(\mathrm{CH}, \mathrm{Ar}) 125.33(\mathrm{CH}, \mathrm{Ar}) 127.02\left(4^{\circ}, \mathrm{Ar}\right) 127.40\left(4^{\circ}, \mathrm{Ar}\right) 136.98$ (4, Ar) 162.64 (4 $\left.4^{\circ}, \mathrm{C}=\mathrm{O}\right)$; Anal. calcd for $\mathrm{C}_{10} \mathrm{H}_{9 N O}$ : C, 68.56; H, 5.18; N, 8.00. Found: C, 68.45; H, 5.22; N, 7.74.

(2-(Methoxycarbonyl)indole-3-yl)methyl trimethyl ammonium iodide (8). To a stirred solution of 7 (14.015 g, $80 \mathrm{mmol}$ ) in $\mathrm{AcOH}$ (40 ml) was added aqueous $\mathrm{Me} 2 \mathrm{NH}(50 \%, 6.79 \mathrm{ml}, 88 \mathrm{mmol})$ and aqueous $\mathrm{HCHO}(37 \%, 6.6 \mathrm{ml}, 88 \mathrm{mmol})$ at room temperature. The mixture was stirred under reflux for $16 \mathrm{~h}$. To the reaction mixture was added aqueous saturated $\mathrm{NaHCO}_{3}$ at $0^{\circ} \mathrm{C}$ until the mixture become basic. The aqueous layer was extracted with ether ( $200 \mathrm{ml}$ x 3), dried over $\mathrm{MgSO}_{4}$, filtered, and concentrated in vacuo. The residue was purified by recrystallization (hexane/EtOAc) to give methyl 3-(N,N-dimethylaminomethyl)indole-2-carboxylate (6.202 g, 33\%) as colorless prisms: $\mathrm{mp}$ 89-91 ${ }^{\circ} \mathrm{C}$; IR $v_{\max }\left(\mathrm{CHCl}_{3}\right) \mathrm{cm}^{-1}$ 3346, 1705, 1456, 1254, 1209; ${ }^{1} \mathrm{H}-\mathrm{NMR}\left(\mathrm{CDCl}_{3}\right) \delta 2.22(6 \mathrm{H}, \mathrm{s}$, NMe2) 3.85, $3.86\left(\mathrm{~s}, 5 \mathrm{H}, \mathrm{CH}_{2} \mathrm{~N}, \mathrm{CO}_{2} \mathrm{Me}\right)$ 7.05-7.29 (3H, m, Ar-H) $7.76(1 \mathrm{H}, \mathrm{d}, J=8.3 \mathrm{~Hz}$, indole-8-H) $8.80(1 \mathrm{H}, \mathrm{br}, \mathrm{NH})$; ${ }^{13} \mathrm{C}-\mathrm{NMR}\left(\mathrm{CDCl}_{3}\right) \delta 45.66\left(\mathrm{CH}_{3}, \mathrm{NMe} 2\right) 51.77\left(\mathrm{CH}_{3}, \mathrm{CO}_{2} \mathrm{Me}\right)$ $52.79\left(\mathrm{CH}_{2}\right) 111.66(\mathrm{CH}, \mathrm{Ar}) 120.46(\mathrm{CH}, \mathrm{Ar}) 120.73\left(4^{\circ}, \mathrm{Ar}\right) 121.63(\mathrm{CH}, \mathrm{Ar}) 124.38\left(4^{\circ}, \mathrm{Ar}\right)$ 125.55 (CH, Ar) $128.53\left(4^{\circ}, \mathrm{Ar}\right) 135.74\left(4^{\circ}, \mathrm{Ar}\right) 162.55$ (4, C=O).

To a stirred solution of give methyl 3-( $N, N$-dimethylaminomethyl)indole2-carboxylate (5.087 g, $25 \mathrm{mmol})$ in THF $(125 \mathrm{ml})$ was added MeI $(1.55 \mathrm{ml}, 25 \mathrm{mmol})$ at room temperature. The mixture was stirred under reflux for $20 \mathrm{~h}$. After cooling, the precipitated solid was filtered and washed with benzene thoroughly to give 8 (9.82 g, quant.). The analytical sample was recrystallized with $\mathrm{MeOH} /$ benzene/hexane to give colorless needles: mp $218-220^{\circ} \mathrm{C}$; IR $v_{\max }\left(\mathrm{CHCl}_{3}\right) \mathrm{cm}^{-1}$ 3180, 1703, 1460, 1377, 1254; ${ }^{1} \mathrm{H}-\mathrm{NMR}$ (CD3OD) $\delta 3.19$ (9H, s, NMe3) 4.01 
$\left(3 \mathrm{H}, \mathrm{s}, \mathrm{CO}_{2} \mathrm{Me}\right) 4.56\left(2 \mathrm{H}, \mathrm{s}, \mathrm{CH}_{2} \mathrm{~N}\right) 7.28(1 \mathrm{H}, \mathrm{t}, J=7.22 \mathrm{~Hz}, \mathrm{Ar}-\mathrm{H}) 7.41(1 \mathrm{H}, \mathrm{t}, J=6.9 \mathrm{~Hz}, \mathrm{Ar}-\mathrm{H})$ $7.57(1 \mathrm{H}, \mathrm{d}, J=7.6 \mathrm{~Hz}, \mathrm{Ar}-\mathrm{H}) 7.86\left(1 \mathrm{H}, \mathrm{d}, J=7.9 \mathrm{~Hz}\right.$, indole-8-H);; Anal. calcd for $\mathrm{C}_{14} \mathrm{H}_{19} \mathrm{IN}_{2} \mathrm{O}_{2}$ : C, 44.93; H, 5.12; N, 7.49. Found: C, 44.49; H, 5.11; N, 3.33.

\section{tert-Butyl(1S,2S,5S)-(2-hydroxy-2,6,6-trimethyl-bicyclo[3.1.1]hept-3-ylidene-amino)acetate}

(10). ${ }^{3 \mathrm{~b}}$ To a stirred solution of Z-Gly-OBut (10.98 mg, $\left.41.4 \mathrm{mmol}\right)$ in EtOAc (70 ml) was added 5\% $\mathrm{Pd} / \mathrm{C}(1 \mathrm{~g})$ under argon atmosphere at room temperature. The mixture was stirred for $1 \mathrm{~h}$ at room temperature under $\mathrm{H}_{2}$ atmosphere. The mixture was filtered and concentrated in vacuo. The volatile amine was used for the next step without further purification.

In a $200 \mathrm{ml}$ round bottled flask, equipped with a Dean Stark apparatus (molecular sieves type 4) and reflux condenser, the crude amine $(41.4 \mathrm{mmol})$ was dissolved in benzene $(60 \mathrm{ml})$, followed by addition of (-)-HyPN (9) (3.48 g, $20.7 \mathrm{mmol})$ and $\mathrm{BF} 3 \cdot \mathrm{Et}_{2} \mathrm{O}(0.13 \mathrm{ml}, 1.1 \mathrm{mmol})$. The mixture was stirred under reflux for $15 \mathrm{~h}$. The mixture was concentrated in vacuo. The residue was purified by column chromatography (silica gel BW-820MH, 150 g, hexane:EtOAc $=2: 1$ to 1:1) to give $\mathbf{1 0}$ (5.56 g, 97\%) as a colorless oil; IR $v_{\text {max }}$ neat $\mathrm{cm}^{-1}$ 3432, 1743, 1655, 1369, 1151; $1_{\mathrm{H}-\mathrm{NMR}}$ $\left(\mathrm{CDCl}_{3}\right) \delta 0.87$ (3H, s, Me2C) 1.33 (3H, s, Me2C) 1.48 (9H, s, Me3C) 1.52 (3H, s, CH3C $(\mathrm{OH})$ ) 1.69-1.90 (2H decreased with $\mathrm{D}_{2} \mathrm{O}$ to $\left.1 \mathrm{H}, \mathrm{CHCH}_{2} \mathrm{CH}, \mathrm{OH}\right) 2.00-2.10\left(2 \mathrm{H}, \mathrm{m}, \mathrm{CHCH}_{2} \mathrm{CH}\right)$ 2.30-2.40 (1H, m, $\left.\mathrm{CHCH}_{2} \mathrm{CH}\right) 2.47\left(2 \mathrm{H}, \mathrm{s}, \mathrm{CH}_{2} \mathrm{C}=\mathrm{N}\right) 4.08\left(2 \mathrm{H}, \mathrm{s}, \mathrm{NCH}_{2} \mathrm{CO}_{2}\right)$.

\section{Methyl 3-[(1S,2S,5S)-2-(2-hydroxy-2,6,6-trimethyl-bicyclo[3.1.1]hept-3-ylidene-} amino-(2S)-tert-butoxycarbonyl-ethyl]-1H-indole-2-carboxylate (11). To a stirred solution of $i$-Pr2NH (6.1 ml, $43.5 \mathrm{mmol}$ ) in THF (40 ml) was added $1.6 \mathrm{M}$ solution of $n$-butyllithium in hexane ( $28 \mathrm{ml}, 43.4 \mathrm{mmol}$ ) dropwise at $-78^{\circ} \mathrm{C}$. The mixture was stirred for $40 \mathrm{~min}$ at $-78^{\circ} \mathrm{C}$. To the LDA solution was added a solution of $\mathbf{1 0}$ (5.56 g, $19.8 \mathrm{mmol})$ in THF ( $20 \mathrm{ml}$ plus $5 \mathrm{ml}$ of THF rinse). The mixture was stirred for $30 \mathrm{~min}$ at $-78^{\circ} \mathrm{C}$. The ammonium salt 8 was added to the reaction mixture, followed by stirring at $-78^{\circ} \mathrm{C}$ for $2 \mathrm{~h}$ and at $4^{\circ} \mathrm{C}$ for $11 \mathrm{~h}$. The reaction was quenched with saturated aqueous $\mathrm{NH}_{4} \mathrm{Cl}(50 \mathrm{ml})$. The aqueous layer was extracted with EtOAc $(100 \mathrm{ml} \times \mathrm{x}$ ), dried over $\mathrm{Na}_{2} \mathrm{SO}_{4}$, filtered, and concentrated in vacuo. The residue was purified by column chromatography (silica gel BW-200, $150 \mathrm{~g}$, hexane:EtOAc = 3:1) to give $\mathbf{1 1}$ as a light yellow oil, which was used for the next step without further purification; IR $v_{\max }$ neat $\mathrm{cm}^{-1} 3300,1717,1456,1257 ;{ }^{1} \mathrm{H}-\mathrm{NMR}$ (CDCl3) $\delta 1.12$ (3H, s, Me2C) 1.16 (3H, s, Me2C) 1.28-1.91 (8H, m, $\mathrm{CH}_{3} \mathrm{C}(\mathrm{OH}), \mathrm{CHCH}_{2} \mathrm{CH}$, $\left.\mathrm{CH}_{2} \mathrm{C}=\mathrm{N}\right) 1.45(9 \mathrm{H}, \mathrm{s}, \mathrm{CMe} 3) 2.09\left(2 \mathrm{H}, \mathrm{m}, \mathrm{CHCH}_{2} \mathrm{CH}\right) 3.75\left(2 \mathrm{H}, \mathrm{d}, J=4.3 \mathrm{~Hz}, \mathrm{CH}_{2} \mathrm{CHN}\right) 4.02$ $\left(3 \mathrm{H}, \mathrm{s}, \mathrm{CO}_{2} \mathrm{Me}\right) 4.19(1 \mathrm{H}, \mathrm{t}, J=7.0 \mathrm{~Hz}, \mathrm{CHN}) 7.13-7.20(3 \mathrm{H}, \mathrm{m}, \mathrm{Ar}-\mathrm{H}) 7.81(1 \mathrm{H}, \mathrm{d}, J=7.9 \mathrm{~Hz}$, indole-8-H) 8.73 (1H, brs, $\mathrm{NH})$. 


\section{(R)-tert-Butyl 3-(2-(methoxycarbonyl)indol-3-yl)-2- $N$-(tert-butoxycarbonyl)-amino-}

propionate (2). To a stirred solution of the crude 11 (4.693 g, $9.9 \mathrm{mmol})$ in THF (40 ml) was added $15 \%$ aqueous citric acid $(40 \mathrm{ml})$ at room temperature. The mixture was stirred for 1 day at room temperature. After evaporation of THF, EtOAc $(30 \mathrm{ml})$ was added and the mixture was extracted with $15 \%$ aqueous citric acid (50 $\mathrm{ml} \mathrm{x} \mathrm{3).} \mathrm{The} \mathrm{aqueous} \mathrm{layer} \mathrm{was} \mathrm{basified} \mathrm{with} \mathrm{NaHCO}_{3}$ in an ice bath, followed by salting out, and extracted with ether (100 $\mathrm{ml} \mathrm{x} \mathrm{3).} \mathrm{The} \mathrm{organic} \mathrm{layer} \mathrm{was} \mathrm{washed}$ with saturated brine $(50 \mathrm{ml})$, dried over $\mathrm{MgSO} 4$, filtered, and concentrated in vacuo to give the crude amine 12 which was immediately used for the next step without further purification.

To a stirred solution of the crude amine $(9.9 \mathrm{mmol})$ in dioxane $(30 \mathrm{ml})$ was added Boc2O $(4.3 \mathrm{~g}$, $19.8 \mathrm{mmol}$ ) at room temperature. The mixture was stirred for $11.5 \mathrm{~h}$ at room temperature. After evaporation of the volatile, the residue was purified by column chromatography (silica gel BW-200, $120 \mathrm{~g}$, hexane:EtOAc $=6: 1$ to 4:1) to give 2 (2.605 g, 63\% in 3 steps, 87\%ee) as a colorless solid. The analytical sample was recrystallized with hexane/EtOAc to give $\mathbf{2}$ as colorless needles (91\%ee); mp $129^{\circ} \mathrm{C}$; $[\alpha] \mathrm{D}^{26}-7.45$ (c 1.20, $\left.\mathrm{CHCl}_{3}\right)$; IR $v_{\max }\left(\mathrm{CHCl}_{3}\right) \mathrm{cm}^{-1} 3351,2978,1738,1368,1256$,

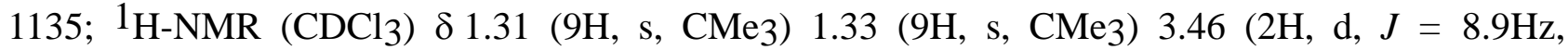
$\left.\mathrm{CH}_{2} \mathrm{CH}\right) 3.97$ (3H, s, CO2Me) 4.50 (1H, dd, $\left.J=6.6,8.6 \mathrm{~Hz}, \mathrm{CHCH}_{2}\right) 5.31$ (1H, brd, NH) 7.14-7.38 (3H, m, Ar-H) $7.74\left(1 \mathrm{H}, \mathrm{d}, J=7.9 \mathrm{~Hz}\right.$, indole-8-H) 8.78 (1H, brs, indole-NH); ${ }^{13} \mathrm{C}-\mathrm{NMR}\left(\mathrm{CDCl}_{3}\right)$

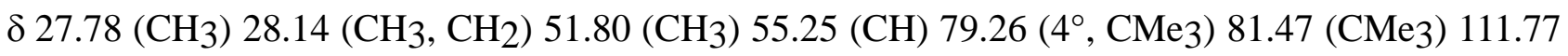
(CH, Ar) 119.24 (4 , Ar CCO2Me) 120.41 (CH, Ar) 120.81 (CH, Ar) 123.88 (4 , Ar) 125.69 (CH, Ar) $127.99\left(4^{\circ}, \mathrm{Ar}\right) 135.86\left(4^{\circ}, \mathrm{Ar}\right) 155.16\left(4^{\circ}, \mathrm{NHCO}_{2}\right) 162.62\left(4^{\circ}, \mathrm{CO}_{2} \mathrm{Me}\right) 171.57\left(4^{\circ}\right.$, $\left.\mathrm{CO}_{2}{ }^{\mathrm{Bu}}\right)$; Anal. calcd for $\mathrm{C}_{22} \mathrm{H}_{30} \mathrm{~N}_{2} \mathrm{O}_{6}$ : C, 63.14; H, 7.23; N, 6.69. Found: C, 62.94; H, 7.19; N, 6.68; HPLC analysis for 2: column, Daicel Chiralcel OD; solvent, hexane/i-PrOH = 9:1; flow, 1.0 $\mathrm{ml} / \mathrm{min}$; retention time, 9.03, $9.70 \mathrm{~min}$.

Boc-D-Asp(OH)-OBu ${ }^{t}$ (13). To a stirred solution of 2 (67.1 mg, $0.16 \mathrm{mmol}$, 87\% ee) in EtOAc (0.4 $\mathrm{ml}), \mathrm{MeCN}(0.4 \mathrm{ml})$, and $\mathrm{H}_{2} \mathrm{O}(4 \mathrm{ml})$ was added $\mathrm{NaIO}_{4}(856 \mathrm{mg}, 4 \mathrm{mmol})$ and $\mathrm{RuCl}_{3} \cdot n \mathrm{H}_{2} \mathrm{O}(2.0$ mg, $0.0096 \mathrm{mmol}$ ) at room temperature. The mixture was stirred at room temperature for $12.5 \mathrm{~h}$. Aqueous $\mathrm{KHSO}_{4}(1 \mathrm{M}, 5 \mathrm{ml})$ was added to the reaction mixture and the aqueous layer was extracted with EtOAc (10 ml x 3). The organic layer was washed with saturated brine (10 ml), dried over $\mathrm{Na}_{2} \mathrm{SO}_{4}$, filtered, and concentrated in vacuo to give the crude carboxylic acid $\mathbf{1 3}$ which was used for the next step without further purification.

Boc-D-Asp(OMe)-OBu ${ }^{t}$ (14). To a stirred solution of the crude carboxylic acid $13(0.16 \mathrm{mmol})$ in DMF (1 ml) was successively added $\mathrm{KHCO}_{3}(24 \mathrm{mg}, 0.24 \mathrm{mmol})$ and $\mathrm{MeI}(40 \mu \mathrm{l}, 0.64 \mathrm{mmol})$ at $0^{\circ} \mathrm{C}$. The mixture was stirred for $4 \mathrm{~h}$ at room temperature. After dilution with ether (30 $\mathrm{ml}$ ), the 
organic layer was washed with 1M aqueous KHSO4 $(10 \mathrm{ml})$, saturated brine $(10 \mathrm{ml})$, dried over $\mathrm{MgSO}_{4}$, filtered, and concentrated in vacuo. The residue was purified by column chromatography (silica gel BW-200, 7 g, hexane:EtOAc = 10:1) to give 14 (30.4 mg, 63\% in 2 steps) as a light yellow oil. [ $\alpha$ ] $\mathrm{D}^{17}-16.60$ (c 1.44, $\mathrm{CHCl}_{3}$ ); IR $v_{\max }\left(\mathrm{CHCl}_{3}\right) \mathrm{cm}^{-1}$ 3400, 1745, 1717, 1368, 1155;

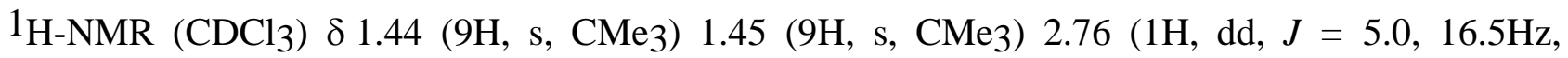
$\left.\mathrm{CH}_{2} \mathrm{CO}_{2} \mathrm{Me}\right) 2.95$ (1H, dd, $\left.J=4.6,16.8 \mathrm{~Hz}, \mathrm{CH}_{2} \mathrm{CO}_{2} \mathrm{Me}\right) 3.69$ (3H, s, CO2Me) 4.43-4.46 (1H, m, CHNH) 5.44 (1H, d, $J=7.9 \mathrm{~Hz}, \mathrm{NH})$. (lit. ${ }^{5}$ ent-14: ${ }^{1} \mathrm{H}-\mathrm{NMR}\left(\mathrm{CDCl}_{3}\right) \delta 1.45$ (18H, s, CMe3) 2.84 (2H, dd, $\left.\mathrm{CH}_{2} \mathrm{CO}_{2} \mathrm{Me}\right) 3.70$ (3H, s, CO2Me) 4.45 (1H, m, CHNH) 5.42 (1H, brs, NH).).

Boc-D-HomoSer-OBu$^{t}$ (15). To a stirred solution of 14 (29.3 mg, $\left.0.097 \mathrm{mmol}\right)$ in THF (0.5 ml) was added $0.5 \mathrm{~N}$ aqueous $\mathrm{LiOH}(0.22 \mathrm{ml}, 0.11 \mathrm{mmol})$ at $0^{\circ} \mathrm{C}$. The mixture was stirred for $6 \mathrm{~h}$ at $0^{\circ} \mathrm{C}$. After acidification with $1 \mathrm{M}$ aqueous $\mathrm{KHSO}_{4}$, the aqueous layer was dried over $\mathrm{Na}_{2} \mathrm{SO}_{4}$, filtered, and concentrated in vacuo to give the crude carboxylic acid, which was used for the next step without further purification.

To a stirred solution of the carboxylic acid $(0.97 \mathrm{mmol})$ in THF $(0.5 \mathrm{ml})$ was added Et3N $(21 \mathrm{ml}$, $0.146 \mathrm{mmol})$ and $\mathrm{ClCO}_{2} \mathrm{Et}(14 \mathrm{ml}, 0.146 \mathrm{mmol})$ successively at $-10^{\circ} \mathrm{C}$, followed by stirring for 30 min. Triethylammonium chloride was removed by filtration and washed with small amount of THF. A solution of sodium borohydride $(8 \mathrm{mg}, 0.21 \mathrm{mmol})$ in water $(0.5 \mathrm{ml})$ was added dropwise to the filtrate at $0^{\circ} \mathrm{C}$, followed by stirring at $0^{\circ} \mathrm{C}$ for $30 \mathrm{~min}$. After being quenched with $1 \mathrm{M}$ aqueous $\mathrm{KHSO}_{4}(3 \mathrm{ml})$, the mixture was extracted with EtOAc $\left(10 \mathrm{ml}\right.$ x 3), dried over $\mathrm{Na}_{2} \mathrm{SO}_{4}$, filtered, and concentrated in vacuo. The residue was purified by column chromatography (silica gel BW-200, 7 g, hexane:EtOAc = 3:1) to give 15 (21.0 mg, 82\% in 3 steps) as a colorless oil. [ $\alpha]_{D^{14}} 32.3^{\circ}$ (c 1.09 , $\mathrm{CHCl}_{3}$ ) (lit. ${ }^{6}$ ent-15 $[\alpha]_{\mathrm{D}}{ }^{25}+37.5^{\circ}$ (c 1.09, $\left.\mathrm{CHCl}_{3}\right)$ ); IR $v_{\max }\left(\mathrm{CHCl}_{3}\right) \mathrm{cm}^{-1} 3400,1730,1694$, 1507, 1367, 1154; 1 ${ }^{\mathrm{H}-\mathrm{NMR}}$ (CDCl3) $\delta 1.45$ (9H, s, CMe3) 1.47 (9H, s, CMe3) 1.50-1.53 (2H, m, $\left.\mathrm{CHCH}_{2}\right)$ 2.10-2.17 (1H, m, $\left.\mathrm{CHCH}_{2}\right) 3.00\left(1 \mathrm{H}, \mathrm{br}\right.$, disappeared with $\left.\mathrm{D}_{2} \mathrm{O}, \mathrm{OH}\right)$ 3.59-3.70 (2H, m, $\left.\mathrm{CH}_{2} \mathrm{OH}\right) 4.31-4.38(1 \mathrm{H}, \mathrm{m}, \mathrm{CHN}) 5.34(1 \mathrm{H}, \mathrm{d}, J=7.6 \mathrm{~Hz}, \mathrm{NH})$. The IR and ${ }^{1} \mathrm{H}-\mathrm{NMR}$ spectra are identical with those of the reported ones.

$\alpha$-Ethyl $\beta$-benzyl 3-oxo-4- $N$-(tert-butoxycarbonyl)aminoadipate (17). To a stirred solution of 16 (327 mg, $1.01 \mathrm{mmol}$ ) in THF (4 ml) was added carbonyldiimidazole (CDI) at $0^{\circ} \mathrm{C}$. The mixture was stirred at room temperature for $6 \mathrm{~h}$. In another flask, to a stirred suspension of magnesium salt of ethyl hydrogen malonate $(0.735 \mathrm{mmol})$, prepared from ethyl hydrogen malonate (194 mg, 1.47 $\mathrm{mmol}$ ) and magnesium ethoxide (84 $\mathrm{mg}, 0.735 \mathrm{mmol}$ ) by the method reported by S. Masamune, ${ }^{7}$ in THF (4 ml) was added the solution of imidazolide via canula, and rinsed with THF (2 ml). The reaction mixture was stirred for $20 \mathrm{~h}$ at room temperature. After dilution with EtOAc (100 ml), the 
mixture was washed with 1M aqueous $\mathrm{KHSO}_{4}(30 \mathrm{ml})$, saturated brine (30 ml), dried over $\mathrm{Na}_{2} \mathrm{SO}_{4}$, filtered, and concentrated in vacuo. The residue was purified by column chromatography (silica gel BW-200, 20 g, hexane:EtOAc $=5: 1)$ to give $17(291 \mathrm{mg}, 78 \%)$ as a colorless solid: $\mathrm{mp} 46-48^{\circ} \mathrm{C}$ (hexane/ether); $[\alpha]_{\mathrm{D}}^{18}-15.81$ (c 1.35, $\mathrm{CHCl}_{3}$ ); IR $v_{\max }\left(\mathrm{CHCl}_{3}\right) \mathrm{cm}^{-1} 3400,1715,1505,1456$, 1163; ${ }^{1} \mathrm{H}-\mathrm{NMR}\left(\mathrm{CDCl}_{3}\right) \delta 1.27\left(3 \mathrm{H}, \mathrm{t}, J=7.3 \mathrm{~Hz}, \mathrm{CH}_{3} \mathrm{CH}_{2}\right) 1.45(9 \mathrm{H}, \mathrm{s}, \mathrm{CMe}) 2.81(1 \mathrm{H}, \mathrm{dd}, J=$ 4.3, 17.2Hz, CH2 $\left.\mathrm{CO}_{2} \mathrm{Bzl}\right) 3.05\left(1 \mathrm{H}, \mathrm{dd}, J=5.0,17.5 \mathrm{~Hz}, \mathrm{CH}_{2} \mathrm{CO}_{2} \mathrm{Bzl}\right) 3.61(2 \mathrm{H}, \mathrm{d}, J=1.7 \mathrm{~Hz}$, $\left.\mathrm{EtO}_{2} \mathrm{CCH}_{2}\right) 4.18\left(2 \mathrm{H}, \mathrm{q}, J=7.3 \mathrm{~Hz}, \mathrm{CH}_{3} \mathrm{CH}_{2}\right)$ 4.56-4.61 (1H, m, CHN) 5.12 (2H, s, CH2 $\left.\mathrm{Ph}\right) 5.64$ (1H, brd, $J=8.9 \mathrm{~Hz}, \mathrm{NH})$ 7.34-7.40 (5H, m, Ar-H); ${ }^{13} \mathrm{C}-\mathrm{NMR}\left(\mathrm{CDCl}_{3}\right) \delta 13.96\left(\mathrm{CH}_{3}\right) 28.17\left(\mathrm{CH}_{3}\right)$ $35.25\left(\mathrm{CH}_{2}\right) 45.84\left(\mathrm{CH}_{2}\right) 55.94(\mathrm{CH}) 61.36\left(\mathrm{CH}_{2}\right) 66.82\left(\mathrm{CH}_{2}\right) 80.46\left(4^{\circ}, \mathrm{CMe}\right) 128.14(\mathrm{CH}, \mathrm{Ar})$

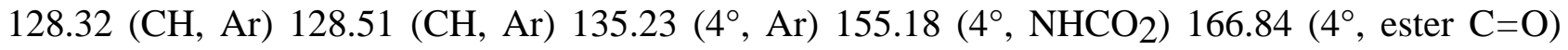

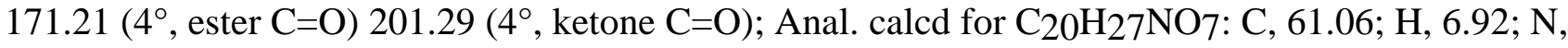
3.56. Found: C, 61.08; H, 6.87; N, 3.62.

$\alpha$-Ethyl $\beta$-hydrogen (S)-3-oxo-4- $N$-(tert-butoxycarbonyl)aminoadipate (18). To a stirred solution of 17 (48.6 mg, $0.15 \mathrm{mmol})$ in EtOAc $(0.5 \mathrm{ml})$ was added 5\% Pd/C (20 mg) under argon atmosphere at room temperature. The mixture was stirred for $1.5 \mathrm{~h}$ at room temperature under hydrogen atmosphere, filtered through a pad of celite, and concentrated in vacuo to give the carboxylic acid $\mathbf{1 8}$ as a colorless oil, which was used for the next step without further purification; IR $v_{\max }{ }^{\text {neat }} \mathrm{cm}^{-1} 3300-3400,1715,1693,1514,1395,1254,1165 ;{ }^{1} \mathrm{H}-\mathrm{NMR}\left(\mathrm{CDCl}_{3}\right) \delta 1.28(3 \mathrm{H}$, t, $\left.J=6.9 \mathrm{~Hz}, \mathrm{CH}_{3} \mathrm{CH}_{2}\right) 1.46(9 \mathrm{H}, \mathrm{s}, \mathrm{CMe} 3)$ 2.68-2.75 (1H, m, $\left.\mathrm{CH}_{2} \mathrm{CO}_{2} \mathrm{H}\right) 2.98(1 \mathrm{H}, \mathrm{dd}, J=6.9 \mathrm{~Hz}$, $\left.\mathrm{CH}_{2} \mathrm{CO}_{2} \mathrm{H}\right) 3.37$ (2H, s, EtO2 $\left.\mathrm{CCH}_{2}\right) 4.21$ (2H, q, $\left.J=6.9 \mathrm{~Hz}, \mathrm{CH}_{3} \mathrm{CH}_{2}\right) 4.44$ (1H, brm, CHN) 5.53 $(1 \mathrm{H}, \mathrm{br}, \mathrm{NH})$ 5-6 (1H, br, disappeared with $\left.\mathrm{D}_{2} \mathrm{O}, \mathrm{CO}_{2} \mathrm{H}\right)$.

(3S,4S)-3-N-(tert-butoxycarbonyl)amino-4-hydroxy-4-(ethoxycarbonyl)-methyl-pyrrolidin-2-o ne (3a) and (3S,4R)-3-N-(tert-butoxycarbonyl)amino-4-hydroxy-

4-(ethoxycarbonyl)methylpyrrolidin-2-one (epi-3a). To a stirred solution of the crude carboxylic acid $18(0.15 \mathrm{mmol})$ in THF (0.5 ml) was added Et3N (23 $\mu \mathrm{l}, 0.165 \mathrm{mmol})$ and ClCO2Et $(16 \mu \mathrm{l}$, $0.165 \mathrm{mmol})$ successively at $0^{\circ} \mathrm{C}$. The mixture was stirred for $3 \mathrm{~h}$. Aqueous $\mathrm{NH} 3(28 \%, 0.1 \mathrm{ml})$ was added to the reaction mixture. The mixture was stirred for $30 \mathrm{~min}$ at $0^{\circ} \mathrm{C}$. After addition of water ( 3 $\mathrm{ml})$, the mixture was extracted with EtOAc $(10 \mathrm{ml} \times 3)$, dried over $\mathrm{Na}_{2} \mathrm{SO}_{4}$, filtered, and concentrated in vacuo. The residue was purified by column chromatography (silica gel BW-200, 7 g, hexane:EtOAc $=1: 2)$ to give a diastereomeric mixture of 3a and $\mathbf{e p i - 3 a ~ ( 3 0 ~} \mathrm{mg}, 86 \%$ ) as a colorless solid. The analytical sample was purified by further column chromatography (silica gel BW-200, $\mathrm{CHCl}: \mathrm{MeOH}=50: 1$ to 10:1) to give the diastereomeric pure 3a and $\boldsymbol{e p i - 3 a . ~}$ 
3a, less polar one: mp $128-132^{\circ} \mathrm{C}$; $[\alpha] \mathrm{D}^{22}+2.75$ (c 1.20, $\left.\mathrm{CHCl}_{3}\right)$; IR $v_{\max }\left(\mathrm{CHCl}_{3}\right) \mathrm{cm}^{-1} 3300$, 1721, 1696, 1514, 1392, 1367, 1271, 1250, 1205, 1169, 756; ${ }^{1} \mathrm{H}-\mathrm{NMR}\left(\mathrm{CDCl}_{3}\right) \delta 1.28(3 \mathrm{H}, \mathrm{t}, J=$ 7.3Hz, $\left.\mathrm{CH}_{3} \mathrm{CH}_{2}\right) 1.45$ (9H, s, CMe3) 2.37 (1H, dd, $\left.J=9.9,16.8 \mathrm{~Hz}, \mathrm{NHCOCH}_{2}\right)$ 2.60-2.70 (1H, m, $\left.\mathrm{NHCOCH}_{2}\right) 2.66\left(1 \mathrm{H}, \mathrm{d}, J=17.2 \mathrm{~Hz}, \mathrm{EtO}_{2} \mathrm{CCH}_{2}\right) 2.99$ (1H, d, $\left.J=16.5 \mathrm{~Hz}, \mathrm{EtO}_{2} \mathrm{CCH}_{2}\right) 4.16-4.24$ (1H, m, CHNHBoc) 4.21 (2H, q, $\left.J=7.3 \mathrm{HZ}, \mathrm{CH}_{3} \mathrm{CH}_{2}\right) 4.85$ (1H, br, disappeared with $\left.\mathrm{D}_{2} \mathrm{O}, \mathrm{OH}\right)$ 5.29 (1H, br, NHBoc) $7.21\left(1 \mathrm{H}\right.$, br, decreased with $\left.\mathrm{D}_{2} \mathrm{O}, \mathrm{NHCO}\right) ; 13 \mathrm{C}-\mathrm{NMR}\left(\mathrm{CDCl}_{3}\right) \delta 13.87$ (CH3) $28.16\left(\mathrm{CH}_{3}\right) 35.11\left(\mathrm{CH}_{2}\right) 42.46\left(\mathrm{CH}_{2}\right) 53.38(\mathrm{CH}) 61.15\left(\mathrm{CH}_{2}\right) 79.74\left(4^{\circ}, \mathrm{CMe}\right) 85.48\left(4^{\circ}\right.$, $\mathrm{C}(\mathrm{OH})$ ) $155.45\left(4^{\circ}, \mathrm{NHCO}_{2}\right) 170.83\left(4^{\circ}\right.$, ester $\left.\mathrm{C}=\mathrm{O}\right) 175.41\left(4^{\circ}\right.$, amide $\left.\mathrm{C}=\mathrm{O}\right)$; Anal. calcd for $\mathrm{C}_{13} \mathrm{H}_{22} \mathrm{~N}_{2} \mathrm{O}_{6}$ : C, 51.65; H, 7.33; N, 9.27. Found: C, 51.29; H, 7.31; N, 9.18.

epi-3a, more polar one: mp $131-133^{\circ} \mathrm{C}$; $[\alpha]_{\mathrm{D}}^{22}-8.07$ (c 0.66, $\mathrm{CHCl}_{3}$ ); IR $v_{\max }\left(\mathrm{CHCl}_{3}\right) \mathrm{cm}^{-1}$ 3300, 1714, 1682, 1537, 1392, 1367, 1252, 1196, 1167, 753; ${ }^{1} \mathrm{H}-\mathrm{NMR}\left(\mathrm{CDCl}_{3}\right) \delta 1.28(3 \mathrm{H}, \mathrm{t}, J=$ 7.3Hz, $\left.\mathrm{CH}_{3} \mathrm{CH}_{2}\right) 1.45(9 \mathrm{H}, \mathrm{s}, \mathrm{CMe} 3) 2.15\left(1 \mathrm{H}, \mathrm{dd}, J=3.3,17.2 \mathrm{~Hz}, \mathrm{NHCOCH}_{2}\right) 2.75(1 \mathrm{H}, \mathrm{d}, J=$ $\left.16.5 \mathrm{~Hz}, \mathrm{EtO}_{2} \mathrm{CCH}_{2}\right) 2.92\left(1 \mathrm{H}, \mathrm{d}, J=17.2 \mathrm{~Hz}, \mathrm{EtO}_{2} \mathrm{CCH}_{2}\right) 2.99(1 \mathrm{H}, \mathrm{d}, J=7.9,16.5 \mathrm{~Hz}$, $\left.\mathrm{NHCOCH}_{2}\right) 4.20$ (2H, q, $\left.J=7.3 \mathrm{HZ}, \mathrm{CH}_{3} \mathrm{CH}_{2}\right) 4.30$ (1H, m, CHNHBoc) 4.48 (1H, br, disappeared with $\left.\mathrm{D}_{2} \mathrm{O}, \mathrm{OH}\right) 5.01$ (1H, br, NHBoc) 6.87 (1H, br, decreased with $\mathrm{D}_{2} \mathrm{O}$, NHCO); 13C-NMR $\left(\mathrm{CDCl}_{3}\right) \delta 13.94\left(\mathrm{CH}_{3}\right) 28.21(\mathrm{CH}) 36.42\left(\mathrm{CH}_{2}\right) 39.85\left(\mathrm{CH}_{2}\right) 56.30(\mathrm{CH}) 56.30(\mathrm{CH}) 61.27\left(\mathrm{CH}_{2}\right)$ $80.10\left(4^{\circ}, \mathrm{CMe}\right) 88.94\left(4^{\circ}, \mathrm{C}(\mathrm{OH})\right) 155.59\left(4^{\circ}, \mathrm{NHCO}_{2}\right) 171.46\left(4^{\circ}\right.$, ester $\left.\mathrm{C}=\mathrm{O}\right) 175.68\left(4^{\circ}\right.$, amide $\mathrm{C}=\mathrm{O}$ ); Anal. calcd for $\mathrm{C}_{13} \mathrm{H}_{22} \mathrm{~N}_{2} \mathrm{O}_{6}$ : C, 51.65; H, 7.33; N, 9.27. Found: C, 51.24; H, 7.18; N, 9.15 .

$\alpha$-2-(Trimethylsilyl)ethyl $\beta$-benzyl 2-oxo-3- $N$-(tert-butoxycarbonyl)amino-adipate (22). To a stirred solution of 16 (3.57 g, $11.04 \mathrm{mmol})$ in THF (20 ml) was added CDI (2.86 g, $17.6 \mathrm{mmol})$ at $0^{\circ} \mathrm{C}$. The mixture was stirred at room temperature for $6 \mathrm{~h}$. In another flask, to a stirred solution of i-Pr2NH $(7.4 \mathrm{ml}, 53 \mathrm{mmol})$ in THF $(100 \mathrm{ml})$ cooled in an ice bath was added dropwise $1.6 \mathrm{M}$ solution of n-butyllithium in hexane (33 ml, $52 \mathrm{mmol}$ ). The mixture was stirred for $30 \mathrm{~min}$ at $0^{\circ} \mathrm{C}$. After cooling at $-78^{\circ} \mathrm{C}$, a solution of trimethylsilylethyl acetate $(8.5 \mathrm{~g}, 53 \mathrm{mmol})$ in THF (50 ml) was added dropwise to the LDA solution. The mixture was stirred for $30 \mathrm{~min}$ at $-78^{\circ} \mathrm{C}$. The solution of the imidazolide was added to the solution of the lithium enolate via canula. The reaction mixture was stirred for $30 \mathrm{~min}$ at $-78^{\circ} \mathrm{C}$, and quenched with $1 \mathrm{M}$ aqueous $\mathrm{KHSO}_{4}(100 \mathrm{ml})$. The aqueous layer was extracted with EtOAc (100 ml x 3). The combined organic layer was dried over $\mathrm{Na}_{2} \mathrm{SO}_{4}$, filtered, and concentrated in vacuo. The residue was purified by column chromatography (silica gel BW-200, 200 g, hexane:EtOAc $=6: 1$ to $4: 1)$ to give $22(4.548 \mathrm{~g}, 92 \%)$ as a colorless oil: $[\alpha]_{\mathrm{D}}^{23}$ -20.29 (c 1.02, $\mathrm{CHCl}_{3}$ ); IR $v_{\max }\left(\mathrm{CHCl}_{3}\right) \mathrm{cm}^{-1}$ 3400, 1745, 1715, 1514, 1456, 1252, 1165; 1 ${ }_{\mathrm{H}-\mathrm{NMR}}\left(\mathrm{CDCl}_{3}\right) \delta 0.034$ (9H, s, SiMe3) 0.98-1.04 (2H, m, TMSCH2) 1.45 (9H, s, СMе3) 2.81 
(1H, dd, $\left.J=4.6,17.2 \mathrm{~Hz}, \mathrm{CH}_{2} \mathrm{CO}_{2} \mathrm{Bzl}\right) 3.05$ (1H, dd, $\left.J=5.0,17.5 \mathrm{~Hz}, \mathrm{CH}_{2} \mathrm{CO}_{2} \mathrm{Bzl}\right) 3.60$ (2H, s, TMSEO2CCH2) 4.18-4.24 (2H, m, TMSCH $\left.2 \mathrm{CH}_{2}\right)$ 4.57-4.60 (1H, m, CHN) 5.12 (2H, s, CH2Ph) $5.63(1 \mathrm{H}, \mathrm{d}, J=9.2 \mathrm{~Hz}, \mathrm{NH})$ 7.34-7.39 (5H, m, Ar-H); 13C-NMR (CDCl3) $\delta-1.59(\mathrm{CH}$, SiMe3) $17.19\left(\mathrm{CH}_{2}\right) 28.21$ (CH3, CMe3) $35.33\left(\mathrm{CH}_{2}\right) 46.03\left(\mathrm{CH}_{2}\right) 55.97(\mathrm{CH}) 63.81\left(\mathrm{CH}_{2}\right) 66.86\left(\mathrm{CH}_{2}\right)$

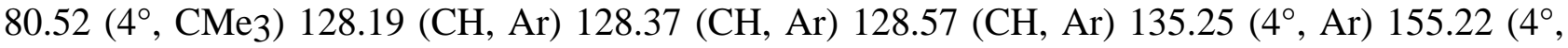

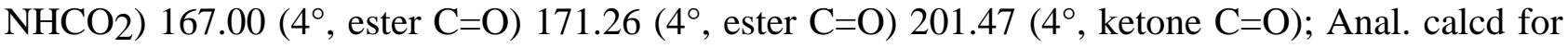
C23H35NO7Si: C, 59.33; H, 7.58; N, 3.01. Found: C, 59.44; H, 7.60; N, 2.89.

(3S,4RS)-3-N-(tert-Butoxycarbonyl)amino-4-[(trimethylsilyl)ethyl]methyl-butyrolactone (24). To a stirred solution of 22 (96 mg, $0.206 \mathrm{mmol})$ in EtOAc $(1 \mathrm{ml})$ was added 5\% Pd/C (40 mg) under argon atmosphere at room temperature. The mixture was stirred for $12 \mathrm{~h}$ under hydrogen atmosphere at room temperature, and filtered through a pad of celite, concentrated in vacuo to give the carboxylic acid $\mathbf{2 3}$ as a colorless oil, which was used for the next step without further purification.

To a stirred solution of the crude carboxylic acid $23(0.206 \mathrm{mmol})$ in EtOH $(1 \mathrm{ml})$ was added $\mathrm{NaBH}_{4}(13 \mathrm{mg}, 0.343 \mathrm{mmol})$ at $0^{\circ} \mathrm{C}$. The mixture was stirred for $15 \mathrm{~min}$ at $0^{\circ} \mathrm{C}$. The reaction mixture was quenched with $1 \mathrm{M}$ aqueous $\mathrm{KHSO}_{4}(3 \mathrm{ml})$, extracted with $\mathrm{CHCl}_{3}(10 \mathrm{ml} \times 3)$, dried over $\mathrm{Na}_{2} \mathrm{SO}_{4}$, filtered, and concentrated in vacuo to give the crude hydroxy acid as a colorless oil, which was used for the next step without further purification.

To a stirred solution of the crude hydroxy acid $(0.206 \mathrm{mmol})$ in $\mathrm{CH}_{2} \mathrm{Cl}_{2}(2 \mathrm{ml})$ was added $\mathrm{EDC} \cdot \mathrm{HCl}(62 \mathrm{mg}, 0.325 \mathrm{mmol})$ and DMAP (3 $\mathrm{mg}, 0.025 \mathrm{mmol})$ successively at $0^{\circ} \mathrm{C}$. The mixture was stirred at $0^{\circ} \mathrm{C}$ for $4 \mathrm{~h}$. After dilution with ether $(30 \mathrm{ml})$, the mixture was washed with $1 \mathrm{M}$ aqueous $\mathrm{KHSO}_{4}(10 \mathrm{ml})$, saturated aqueous $\mathrm{NaHCO}_{3}(10 \mathrm{ml})$, saturated brine $(10 \mathrm{ml})$, dried over MgSO4, filtered, and concentrated in vacuo. The residue was purified by column chromatography (silica gel BW-200, $7 \mathrm{~g}$, hexane:EtOAc = 5:1 to 3:1) to give 24 (61 mg, 82\% in 3 steps) as a colorless oil: $[\alpha] \mathrm{D}^{23}-0.01$ (c 1.735, $\mathrm{CHCl}_{3}$ ); IR $v_{\max }\left(\mathrm{CHCl}_{3}\right) \mathrm{cm}^{-1} 3400,1790,1738,1715,1537$, 1368, 1287; 1 ${ }_{\mathrm{H}-\mathrm{NMR}}\left(\mathrm{CDCl}_{3}\right) \delta 0.034$ (9H, s, SiMe3) 0.96-1.02 (2H, m, TMSCH2) 1.43 (9H, s, CMe3) 2.47 (1H, dd, $J=6.9,18.2 \mathrm{~Hz}, \mathrm{NCHCH}_{2}$ ) 2.71-2.87 (2H, m, TMSEO2CCH2) 3.01 (1H, dd, $\left.J=8.6,17.8 \mathrm{~Hz}, \mathrm{NCHCH}_{2}\right)$ 4.16-4.22 (3H, m, NCHCH, TMSCH $\left.2 \mathrm{CH}_{2}\right)$ 4.60-4.66 (1H, m, CHN) $4.96(1 \mathrm{H}$, brd, $J=5.9 \mathrm{~Hz}, \mathrm{NH})$; ${ }^{13} \mathrm{C}-\mathrm{NMR}\left(\mathrm{CDCl}_{3}\right) \delta-1.97\left(\mathrm{CH}_{3}\right)-1.59\left(\mathrm{CH}_{3}\right)-1.22\left(\mathrm{CH}_{3}\right) 17.18$ $\left(\mathrm{CH}_{2}\right) 28.23\left(\mathrm{CH}_{3}\right) 34.57\left(\mathrm{CH}_{2}\right) 35.11\left(\mathrm{CH}_{2}\right) 35.86\left(\mathrm{CH}_{2}\right) 38.25\left(\mathrm{CH}_{2}\right) 49.41(\mathrm{CH}) 51.50(\mathrm{CH})$ $63.45\left(\mathrm{CH}_{2}\right) 79.24(\mathrm{CH}) 80.43\left(4^{\circ}, \mathrm{CMe}\right) 81.45(\mathrm{CH}) 155.09\left(4^{\circ}, \mathrm{NHCO} 2\right) 169.66\left(4^{\circ}\right.$, ester C=O) 169.88 ( $4^{\circ}$, lactone $\left.\mathrm{C}=\mathrm{O}\right) 173.90\left(4^{\circ}\right.$, lactone $\left.\mathrm{C}=\mathrm{O}\right)$; Anal. calcd for $\mathrm{C}_{16} \mathrm{H}_{29 \mathrm{NO}} \mathrm{Si}$ : C, 53.46; $\mathrm{H}$, 8.13; N, 3.90. Found: C, 53.22; H, 7.94; N, 3.74. 
(3RS,4S)-3-Hydroxy-4-(N-(tert-butoxycarbonyl)amino)adipic acid (26). To a stirred solution of 17 (128 mg, $0.325 \mathrm{mmol})$ in EtOH $(1 \mathrm{ml})$ was added $\mathrm{NaBH} 4(27 \mathrm{mg}, 0.714 \mathrm{mmol})$ at $-78^{\circ} \mathrm{C}$. The mixture was stirred for $1 \mathrm{~h}$ at $-78^{\circ} \mathrm{C}$. Aqueous citric acid $(15 \%, 3 \mathrm{ml})$ was added, and the mixture was allowed to warm to room temperature, and diluted with EtOAc (50 ml), washed with water (10 $\mathrm{ml})$, saturated brine $(10 \mathrm{ml})$, dried over $\mathrm{Na}_{2} \mathrm{SO}_{4}$, filtered, and concentrated in vacuo to give the crude alcohol as a pale yellow oil, which was used for the next step without further purification.

To a stirred solution of the crude alcohol $(0.325 \mathrm{mmol})$ in THF $(1 \mathrm{ml})$ was added dropwise $1 N$ aqueous $\mathrm{NaOH}(0.9 \mathrm{ml}, 0.9 \mathrm{mmol})$ at $0^{\circ} \mathrm{C}$. The mixture was stirred for $5 \mathrm{~h}$ at $0^{\circ} \mathrm{C}$, then transferred to a separating funnel with water $(50 \mathrm{ml})$. The aqueous layer was washed with $\mathrm{CHCl}_{3}(10 \mathrm{ml} \times 2)$, acidified with $1 \mathrm{M}$ aqueous $\mathrm{KHSO}_{4}$ at $0^{\circ} \mathrm{C}$ and salted out. The mixture was extracted with EtOAc (10 ml x 5), dried over $\mathrm{Na}_{2} \mathrm{SO}_{4}$, filtered, and concentrated in vacuo to give the crude 27, which was purified by recrystallization (EtOAc) to give 27 (92 mg, quant.) as a colorless solid: mp $148-151^{\circ} \mathrm{C}$ (EtOAc); $[\alpha]_{\mathrm{D}}^{19}-0.09$ (c 1.02, $\left.\mathrm{MeOH}\right) ; \mathrm{IR} v_{\max }\left(\mathrm{CHCl}_{3}\right) \mathrm{cm}^{-1} 3350,3000-3500,1692,1460$, 1377, 1165; ${ }^{1} \mathrm{H}-\mathrm{NMR}(\mathrm{CD} 3 \mathrm{OD}) \delta 1.42$ (9H, s, CMe3) 2.38-2.44 (2H, m, CH2CO2H) 2.54-2.73 $\left(2 \mathrm{H}, \mathrm{m}, \mathrm{CH}_{2} \mathrm{CO}_{2} \mathrm{H}\right)$ 3.85-3.93 (2H, m, CHOH, CHNH); Anal. calcd for $\mathrm{C}_{11} \mathrm{H} 19 \mathrm{NO}_{7}$ : C, 47.65; $\mathrm{H}$, 6.91; N, 5.05. Found: C, 47.41; H, 6.87; N, 5.08.

Boc-Sarcosine tricloroethylester (Boc-MeGly-OTce). To a stirred solution of Boc-sarcosine (3.78 g, $20 \mathrm{mmol})$ in $\mathrm{CH}_{2} \mathrm{Cl}_{2}(50 \mathrm{ml})$ was successively added TceOH (2.4 ml, $\left.25 \mathrm{mmol}\right)$, EDC $\cdot \mathrm{HCl}(4.38$ g, $23.0 \mathrm{mmol}$ ), and DMAP (244 $\mathrm{mg}, 2.0 \mathrm{mmol}$ ) at $0^{\circ} \mathrm{C}$. The mixture was stirred at room temperature for $19 \mathrm{~h}$. After dilution with $\mathrm{CH}_{2} \mathrm{Cl}_{2}(200 \mathrm{ml})$, the mixture was washed with $1 \mathrm{M}$ aqueous $\mathrm{KHSO}_{4}$ (50 $\mathrm{ml} \times 2$ ), saturated aqueous $\mathrm{NaHCO}_{3}(50 \mathrm{ml})$, saturated brine $(50 \mathrm{ml})$, dried over $\mathrm{Na}_{2} \mathrm{SO}_{4}$, filtered, and concentrated in vacuo. The residue was purified by column chromatography (silica gel BW-200, 200 g, hexane:EtOAc = 7:1 to 5:1) to give Boc-MeGly-OTce (5.892 g, 92\% ) as a colorless oil; IR $v_{\max }$ neat $\mathrm{cm}^{-1}$ 1771, 1700, 1481, 1452, 1390, 1248, 1175; ${ }^{1} \mathrm{H}-\mathrm{NMR}\left(\mathrm{CDCl}_{3}\right)$ $\delta$ 1.43, 1.47 (9H, s, СМе3) 2.96, 2.97 (3H, s, NMe) 4.07, 4.13 (2H, s, NCH2) 4.78 (2H, s, $\left.\mathrm{CH}_{2} \mathrm{CCl}_{3}\right)$; ${ }^{13} \mathrm{C}-\mathrm{NMR}\left(\mathrm{CDCl}_{3}\right) \delta$ 28.16, $28.21\left(\mathrm{CH}_{3}\right)$ 35.45, $35.54\left(\mathrm{CH}_{3}\right)$ 50.10, $50.65\left(\mathrm{CH}_{2}\right)$

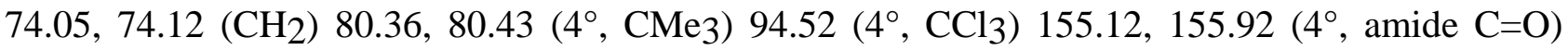
168.40 (CO2Tce); Anal. calcd for $\mathrm{C}_{10} \mathrm{H}_{16} \mathrm{Cl}_{3} \mathrm{NO}_{4}$ : C, 37.46; H, 5.03; N, 4.37. Found: C, 37.41; H, 5.11; N, 4.41.

Boc-Lactone 27. To a stirred solution of 26 (345 mg, $1.25 \mathrm{mmol}$ ) in $\mathrm{CH}_{2} \mathrm{Cl}_{2}$ (13 ml) and DMSO $(13 \mathrm{ml})$ were added $\mathrm{EDC} \cdot \mathrm{HCl}(358 \mathrm{mg}, 1.88 \mathrm{mmol})$ and DMAP $(16 \mathrm{mg}, 0.13 \mathrm{mmol})$ at $0^{\circ} \mathrm{C}$. The mixture was stirred for $17 \mathrm{~h}$ at room temperature. After dilution with ether $(100 \mathrm{ml})$, the mixture was washed with 1M aqueous $\mathrm{KHSO}_{4}(30 \mathrm{ml}$ ), saturated brine (30 ml), dried over MgSO 4 , filtered, 
and concentrated in vacuo to give the crude lactone carboxylic acid (134 mg). The aqueous layer was salted out and extracted with ether $(10 \mathrm{ml} x \mathrm{10})$. The combined organic solution was dried over $\mathrm{MgSO}_{4}$, filtered, and concentrated in vacuo to give the crude $\mathbf{3 b}(312 \mathrm{mg}$ ) as a colorless amorphous solid, which was used for the next step without further purification. (IR $v_{\max }\left(\mathrm{CHCl}_{3}\right) 1786$ $\mathrm{cm}^{-1}$ (lactone $\left.\mathrm{C}=\mathrm{O}\right)$ ).

To a stirred solution of Boc-MeGly-OTce (577 mg, $1.8 \mathrm{mmol})$ in $\mathrm{CHCl}_{3}(4 \mathrm{ml})$ was added TFA $(2 \mathrm{ml})$ at room temperature. The mixture was stirred for $1 \mathrm{~h}$ at room temperature., then concentrated in vacuo to give the light yellow residue. Toluene was added to the whole and the mixture was concentrated in vacuo. This work-up was repeated three times to remove the excess of TFA completely. The crude TFA salt was used for the next step without further purification.

To a stirred solution of the crude $\mathbf{3 b}$ and the crude TFA salt of H-MeGly-OTce were added $\mathrm{BopCl}(510 \mathrm{mg}, 2.0 \mathrm{mmol})$ and $\mathrm{Et} 3 \mathrm{~N}(0.56 \mathrm{ml}, 4.0 \mathrm{mmol})$ at $0^{\circ} \mathrm{C}$. The mixture was stirred for 2 days at $4^{\circ} \mathrm{C}$. After dilution with EtOAc $(100 \mathrm{ml})$, the mixture was washed with $1 \mathrm{M}$ aqueous $\mathrm{KHSO}_{4}$ (30 $\mathrm{ml}$ ), saturated aqueous $\mathrm{NaHCO}_{3}(30 \mathrm{ml})$, dried over $\mathrm{Na}_{2} \mathrm{SO}_{4}$, filtered, and concentrated in vacuo. The residue was purified by column chromatography (silica gel BW-200, 25 g, hexane : EtOAc = $1:$ 1) to give 27 (302 mg, 58\% from 26) as a 5.3:1 diastereoisomeric mixture. A colorless oil: $\left[\alpha{ }_{\mathrm{D}}{ }^{19}\right.$-0.06 (с 0.80, CHCl3); IR $v_{\text {max neat }} \mathrm{cm}^{-1}$ 3335, 1771, 1705, 1651, 1522, 1367, 1279, 1169 , 756; ${ }^{1} \mathrm{H}-\mathrm{NMR}\left(\mathrm{CDCl}_{3}\right) \delta 1.44(9 \mathrm{H}, \mathrm{s}, \mathrm{CMe} 3) 2.51\left(1 \mathrm{H}, \mathrm{dd}, J=7.6,18.1 \mathrm{~Hz}\right.$, lactone $\left.\mathrm{CH}_{2}\right)$ 2.83-3.15 (1H, dd, $J=7.6,18.1 \mathrm{~Hz}, \mathrm{~N}(\mathrm{Me}) \mathrm{COCH}_{2}$, lactone $\mathrm{CH}_{2}$ ) 3.13 (3H, s, NMe) 4.10-4.29 (3H, m, CHO, Sar $\left.\mathrm{CH}_{2}\right)$ 4.69-4.84 (1H, m, CHNHBoc) $4.78\left(2 \mathrm{H}, \mathrm{s}, \mathrm{CH}_{2} \mathrm{CCl}_{3}\right) 5.28(1 \mathrm{H}, \mathrm{br}, \mathrm{NHBoc})$; Anal. calcd for $\mathrm{C}_{16} \mathrm{H}_{23} \mathrm{Cl}_{3} \mathrm{~N}_{2} \mathrm{O}_{7} \cdot 1 / 4$ EtOAc: C, 41.52; H, 5.12; N, 5.70. Found: C, 41.50; H, 4.87; N, 5.61 .

Methyl (R)-3,4-dihydroxybutanoate (29). In a $300 \mathrm{ml}$, three necked, round-bottled flask mounted with a reflux condenser and thermometer was placed a solution of $(R)$-dimethyl malate (28) (5 ml, $37.7 \mathrm{mmol}$ ) in THF ( $80 \mathrm{ml}$ ). To this was added 10.0-10.2 M borane-methylsulfide complex (3.9 $\mathrm{ml}$, 39.0-39.8 mmol) dropwise at room temperature under stirring during $30 \mathrm{~min}$. The solution was stirred at room temperature until evolution of hydrogen gas ceased (ca. $30 \mathrm{~min}$ ). Then, the flask was cooled with a water-ice bath and stirring was continued for $30 \mathrm{~min}$. To the solution was added $\mathrm{NaBH}_{4}\left(72 \mathrm{mg}, 1.90 \mathrm{mmol}\right.$ ) in one portion (exothermic) under vigorous stirring at $0^{\circ} \mathrm{C}$. When the exothermic reaction subsided, the water bath was removed and the reaction was stirred at room temperature for $30 \mathrm{~min}$. $\mathrm{MeOH}(13 \mathrm{ml})$ and $p$ - $\mathrm{TsOH}(360 \mathrm{mg}, 1.9 \mathrm{mmol})$ were added to the reaction mixture, and the resulting slightly cloudy solution was stirred for $30 \mathrm{~min}$ at room temperature, followed by concentration to give a colorless gum. This was dissolved in benzene (40 ml) and 
$\mathrm{MeOH}$ (40 ml), and the resulting solution was concentrated again: this operation was repeated. To the residue was added benzene $(60 \mathrm{ml})$ and the solution was concentrated, which was repeated to eliminate $\mathrm{MeOH}$ and $\mathrm{B}(\mathrm{OMe}) 3$ as thoroughly as possible to give a clear, colorless gum. The residue was purified by column chromatography (silica gel BW-820MH, $150 \mathrm{~g}$, hexane:EtOAc = 1:19 to EtOAc only) to give 29 (4.562 g, 90\%) as a colorless oil.

Methyl (R)-3-hydroxy-4-p-toluenesulfonyloxybutanoate (30). To a stirred solution of 29 (130 mg, $0.969 \mathrm{mmol})$ in pyridine $(2.5 \mathrm{ml})$ was added $p$ - TsCl $(194 \mathrm{mg}, 1.02 \mathrm{mmol})$ at $0^{\circ} \mathrm{C}$. The mixture was stirred at $4^{\circ} \mathrm{C}$ for $20 \mathrm{~h}$. After dilution with EtOAc $(50 \mathrm{ml})$, the mixture was washed with $1 \mathrm{M}$ aqueous $\mathrm{KHSO}_{4}\left(20 \mathrm{ml}\right.$ x 2), saturated aqueous $\mathrm{NaHCO}_{3}(20 \mathrm{ml})$, saturated brine (20 ml), dried over $\mathrm{Na}_{2} \mathrm{SO}_{4}$, filtered, and concentrated in vacuo. The residue was purified by column chromatography (silica gel BW-200, 20 g, hexane:EtOAc = 5:2 to 2:1) to give 30 (179 mg, 64\%) as a white solid. The analytical sample was purified by recrystallization (hexane/ether): mp 81.5-82.5 ${ }^{\circ} \mathrm{C}$ (hexane/ether); $[\alpha] \mathrm{D}^{26}+6.83$ (c 1.1, $\mathrm{CHCl}_{3}$ ); IR $v_{\max }\left(\mathrm{CHCl}_{3}\right) \mathrm{cm}^{-1} 3580,1732$, 1599, 1439; ${ }^{1} \mathrm{H}-\mathrm{NMR}\left(\mathrm{CDCl}_{3}\right) \delta 2.45$ (3H, s, MeAr) 2.53-2.56 (2H, m, CH2CO2Me) 3.01 (1H, d, J $=5.0 \mathrm{~Hz}$, disappeared with $\left.\mathrm{D}_{2} \mathrm{O}, \mathrm{OH}\right) 3.70\left(3 \mathrm{H}, \mathrm{s}, \mathrm{CO}_{2} \mathrm{Me}\right) 4.04\left(2 \mathrm{H}, \mathrm{d}, J=5.0 \mathrm{~Hz}, \mathrm{TsOCH}_{2}\right)$ 4.22-4.28 (1H, m, CHOH) $7.36(2 \mathrm{H}, \mathrm{d}, J=8.3 \mathrm{~Hz}, \mathrm{SO} 2 \mathrm{Ar}(\mathrm{m})) 7.80(2 \mathrm{H}, \mathrm{d}, J=8.3 \mathrm{~Hz}, \mathrm{SO} 2 \mathrm{Ar}$ (o) ); ${ }^{13} \mathrm{C}-\mathrm{NMR}\left(\mathrm{CDCl}_{3}\right) \delta 21.56\left(\mathrm{CH}_{3}\right) 37.10\left(\mathrm{CH}_{2}\right) 51.93\left(\mathrm{CH}_{3}\right) 65.85(\mathrm{CH}) 71.96\left(\mathrm{CH}_{2}\right) 127.88$ (CH) $129.88(\mathrm{CH}) 132.36\left(4^{\circ}, \mathrm{Ar}\right) 145.08$ (4, $\left.\mathrm{Ar}\right) 171.84\left(4^{\circ}, \mathrm{C}=\mathrm{O}\right)$; Anal. calcd for $\mathrm{C}_{12} \mathrm{H}_{16} \mathrm{O}_{6} \mathrm{~S}$ : C, 49.99; H, 5.59. Found: C, 49.88; H, 5.44.

Methyl (R)-3-hydroxy-4-azidobutanoate (31). To a stirred solution of 30 (50.5 mg, $0.175 \mathrm{mmol}$ ) in DMF $(0.5 \mathrm{ml})$ was added $\mathrm{NaN}_{3}(57 \mathrm{mg}, 0.877 \mathrm{mmol})$ at room temperature. The mixture was stirred at $80{ }^{\circ} \mathrm{C}$ for $3 \mathrm{~h}$. After dilution with EtOAc (50 ml), the mixture was washed with water (20 $\mathrm{ml})$, 1M aqueous $\mathrm{KHSO}_{4}(20 \mathrm{ml})$, saturated brine $(20 \mathrm{ml})$, dried over $\mathrm{MgSO}$, filtered, and concentrated in vacuo. The residue was purified by column chromatography (silica gel BW-200, 7 g, hexane:EtOAc $=3: 1)$ to give $31(23.0 \mathrm{mg}, 83 \%)$ as a colorless oil: $[\alpha]_{\mathrm{D}}^{26}+19.63$ (с 1.03, $\left.\mathrm{CHCl}_{3}\right)$; IR $v_{\max }$ neat $\mathrm{cm}^{-1}$ 3400, 2106, 1441, 1286, 1172; ${ }^{\mathrm{H}-\mathrm{NMR}}\left(\mathrm{CDCl}_{3}\right) \delta 2.54-2.57(2 \mathrm{H}, \mathrm{m}$, $\left.\mathrm{CH}_{2} \mathrm{CO}_{2} \mathrm{Me}\right) 3.15\left(1 \mathrm{H}, \mathrm{s}\right.$, disappeared with $\left.\mathrm{D}_{2} \mathrm{O}, \mathrm{OH}\right) 3.36\left(2 \mathrm{H}, \mathrm{dd}, J=4.3,5.9 \mathrm{~Hz}, \mathrm{CH}_{2} \mathrm{~N}_{3}\right) 3.73$ (3H, s, CO2Me) 4.18-4.24 (1H, m, CHOH); ${ }^{13} \mathrm{C}-\mathrm{NMR}\left(\mathrm{CDCl}_{3}\right) \delta 38.20\left(\mathrm{CH}_{2}\right) 51.91\left(\mathrm{CH}_{3}\right) 55.49$ $\left(\mathrm{CH}_{2}\right) 67.20(\mathrm{CH}) 172.32\left(4^{\circ}, \mathrm{C}=\mathrm{O}\right)$; Anal. calcd for $\mathrm{C}_{5} \mathrm{H}_{9} \mathrm{~N}_{3} \mathrm{O}_{3}$ : C, 37.74; H, 5.70; N, 26.40. Found: C, 37.48; H, 5.68; N, 26.32.

Methyl (R)-3-hydroxy-4- $N$-(tert-butoxycarbonyl)aminobutanoate (32). To a stirred solution of 31 (1.76 g, $11.1 \mathrm{mmol})$ in EtOAc (20 ml) was added 5\% Pd/C (500 mg) and Boc2O (3.63 g, 16.6 mmol) under argon atmosphere. The black slurry was stirred under 1 atom of $\mathrm{H}_{2}$ for $13 \mathrm{~h}$ at room 
temperature. The mixture was filtered through a pad of celite (rinsed with EtOAc) and the filtrate was concentrated in vacuo and purified by column chromatography (silica gel BW-200, 70 g, hexane:EtOAc $=1: 1)$ to give $32(1.721 \mathrm{~g}, 87 \%)$ as a colorless oil: $[\alpha] \mathrm{D}^{26}+5.37^{\circ}$ (c $\left.1.06, \mathrm{CHCl}_{3}\right)$; IR $v_{\text {max }}{ }^{\text {neat }} \mathrm{cm}^{-1} 3400,1738,1715,1520,1368,1271,1252,1169 ;{ }^{1} \mathrm{H}-\mathrm{NMR}\left(\mathrm{CDCl}_{3}\right) \delta 1.44(9 \mathrm{H}$, s, CMe3) 2.48-2.51 (2H, m, $\left.\mathrm{CH}_{2} \mathrm{CO}_{2} \mathrm{Me}\right)$ 3.30-3.38 (2H, m, $\left.\mathrm{NCH}_{2}\right) 3.44$ (1H, s, disappeared with D2O, OH) 3.71 (3H, s, CO2Me) 4.07-4.16 (1H, m, CHOH) 4.96 (1H, brs, NH); ${ }^{13} \mathrm{C}-\mathrm{NMR}\left(\mathrm{CDCl}_{3}\right)$

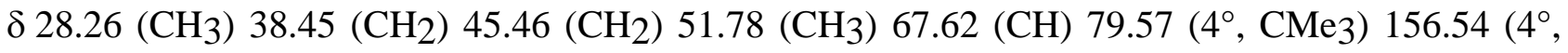
$\mathrm{NHC}=\mathrm{O}) 172.77\left(4^{\circ}, \mathrm{C}=\mathrm{O}\right)$; Anal. calcd for $\mathrm{C}_{10} \mathrm{H}_{19} \mathrm{NO}_{5}$ : C, 51.49; H, 8.21; N, 6.00. Found: C, 51.34; H, 8.43; N, 5.87.

2,2,2-Trichloroethyl (R)-3-hydroxy-4- $N$-(tert-butoxycarbonyl)aminobutanoate (33). To a stirred solution of 32 (1.721 g, $7.38 \mathrm{mmol})$ in $\mathrm{MeOH}(15 \mathrm{ml})$ was added $1 \mathrm{~N}$ aqueous $\mathrm{NaOH}(8.9 \mathrm{ml}, 8.9$ $\mathrm{mmol}$ ) at $0^{\circ} \mathrm{C}$. The mixture was stirred at $0^{\circ} \mathrm{C}$ for $3.5 \mathrm{~h}$, then acidified by addition of $1 \mathrm{M}$ aqueous KHSO4, and salted out. The aqueous layer was extracted with $\mathrm{CHCl}_{3}$ (30 $\mathrm{ml}$ x 4). The combined organic layer was washed with saturated brine $(30 \mathrm{ml})$, dried over $\mathrm{Na}_{2} \mathrm{SO}_{4}$, filtered, and concentrated in vacuo to give the crude carboxylic acid as a colorless oil, which was used for the next step without further purification.

To a stirred solution of the crude carboxylic acid $(7.38 \mathrm{mmol})$ and 2,2,2-trichloroethanol (1.1 ml, $11.5 \mathrm{ml})$ and DMAP (90 mg, $0.73 \mathrm{mmol})$ in $\mathrm{CH}_{2} \mathrm{Cl}_{2}(30 \mathrm{ml})$ was added $\mathrm{EDC} \cdot \mathrm{HCl}(1.7 \mathrm{~g}, 8.92$ $\mathrm{mmol})$ at $0^{\circ} \mathrm{C}$. The mixture was stirred at room temperature overnight. After dilution with EtOAc (200 ml), the mixture was washed with $1 \mathrm{M} \mathrm{KHSO}_{4}\left(50 \mathrm{ml}\right.$ x 2), saturated aqueous $\mathrm{NaHCO}_{3}$ (50 $\mathrm{ml})$, saturated brine $(50 \mathrm{ml})$, dried over $\mathrm{Na}_{2} \mathrm{SO}_{4}$, filtered, and concentrated in vacuo. The residue was purified by column chromatography (silica gel BW-200, $70 \mathrm{~g}$, hexane:EtOAc = 3:2) to give 33 (1.495 g, 59\% in 2 steps) as a white solid: $\mathrm{mp} 70.5-71.5^{\circ} \mathrm{C}$ (hexane); $[\alpha] \mathrm{D}^{23}+2.08$ (c 1.02 , $\mathrm{CHCl}_{3}$ ); IR $v_{\max }{ }^{\text {neat }} \mathrm{cm}^{-1}$ 3400, 1755, 1715, 1539, 1507, 1368, 1279, 1254, 1161; ${ }^{\mathrm{H}-\mathrm{NMR}}$ $\left(\mathrm{CDCl}_{3}\right) \delta 1.45$ (9H, s, CMe3) $2.67\left(2 \mathrm{H}, \mathrm{d}, J=6.3 \mathrm{~Hz}, \mathrm{CH}_{2} \mathrm{CO}_{2} \mathrm{Tce}\right)$ 3.13-3.23 (1H, dt, $J=6.3$, 14.2Hz, $\mathrm{NCH}_{2}$ ) 3.38-3.40 (2H decreased with $\mathrm{D}_{2} \mathrm{O}$ to $\left.1 \mathrm{H}, \mathrm{m}, \mathrm{OH}, \mathrm{NCH}_{2}\right) 4.19$ (1H, br, $\left.\mathrm{CHOH}\right)$ $4.77\left(2 \mathrm{H}, \mathrm{ABq}, J=12.2 \mathrm{~Hz}, \mathrm{CH}_{2} \mathrm{CCl} 3\right) 4.97$ (1H, brs, $\left.\mathrm{NH}\right) ;{ }^{13} \mathrm{C}-\mathrm{NMR}\left(\mathrm{CDCl}_{3}\right) \delta 28.32\left(\mathrm{CH}_{3}\right)$ $38.69\left(\mathrm{CH}_{2}\right) 45.53\left(\mathrm{CH}_{2}\right) 67.63(\mathrm{CH}) 73.98\left(\mathrm{CH}_{2}\right) 79.87\left(4^{\circ}, \mathrm{CMe} 3\right) 94.61\left(4^{\circ}, \mathrm{CCl}_{3}\right) 156.78\left(4^{\circ}\right.$, $\mathrm{NHC}=\mathrm{O}) 170.42\left(4^{\circ}, \mathrm{C}=\mathrm{O}\right)$; Anal. calcd for $\mathrm{C}_{11} \mathrm{H}_{18} \mathrm{Cl}_{3} \mathrm{NO}_{5}: \mathrm{C}, 37.68 ; \mathrm{H}, 5.17 ; \mathrm{N}, 3.99$. Found: $\mathrm{C}$, 37.72; H, 5.07; N, 3.79.

\section{2,2,2-Trichloroethyl (R)-3-(tert-butyldimethyl)siloxy-4- $N$-(tert-butoxy-carbonyl)-}

aminobutanoate (4). To a stirred solution of 33 (1.245 g, $3.55 \mathrm{mmol})$ in DMF (10 ml) cooled in an ice bath was added imidazole (1.2 g, $17.6 \mathrm{mmol})$ and TBSCl (1.2 g, $7.96 \mathrm{mmol})$. The mixture was 
stirred at room temperature for $15 \mathrm{~h}$. After dilution with ether $(200 \mathrm{ml})$, the mixture was washed with $1 \mathrm{M}$ aqueous $\mathrm{KHSO}_{4}$ (30 $\mathrm{ml}$ x 2), saturated aqueous $\mathrm{NaHCO}_{3}$ (30 ml) and saturated brine (30 $\mathrm{ml}$ ), dried over $\mathrm{MgSO}_{4}$, filtered, and concentrated in vacuo. The residue was purified by column chromatography (silica gel BW-200, 60 g, hexane:ether = 9:1 to 8:1) to give $4(1.675 \mathrm{~g}, 100 \%$ ) as a colorless oil: $[\alpha] \mathrm{D}^{23}+8.44$ (c $\left.0.98, \mathrm{CHCl}_{3}\right)$; IR $v_{\max }$ neat $\mathrm{cm}^{-1} 3400,1759,1713,1504,1368$, 1254, 1161; 1 ${ }^{\mathrm{H}-\mathrm{NMR}}\left(\mathrm{CDCl}_{3}\right) \delta 0.06$ (3H, s, SiMe2) 0.09 (3H, s, SiMe2) 0.87 (9H, s, SiCMe3) 1.44 (9H, s, СМе3) 2.62 (2H, d, $J=5.9 H z, \mathrm{CH}_{2} \mathrm{CO}_{2}$ Tce) 3.24-3.29 (2H, m, NCH2) 4.25-4.29 (1H, m, CHOTBS) $4.72\left(2 \mathrm{H}, \mathrm{ABq}, J=12.2 \mathrm{~Hz}, \mathrm{CH}_{2} \mathrm{CCl}_{3}\right)$ 4.71-4.78 (1H, brm, NH); 13C-NMR

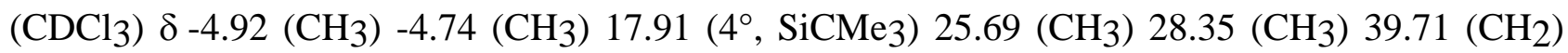
$45.93\left(\mathrm{CH}_{2}\right) 68.08(\mathrm{CH}) 74.08\left(\mathrm{CH}_{2}\right) 79.44\left(4^{\circ}, \mathrm{NHCO} 2 \mathrm{CMe} 3\right) 94.73\left(4^{\circ}, \mathrm{CCl}_{3}\right) 155.86\left(4^{\circ}\right.$, $\mathrm{NHC}=\mathrm{O}) 169.46$ (4, $\mathrm{C}=\mathrm{O})$; Anal. calcd for $\mathrm{C}_{17} \mathrm{H}_{32} \mathrm{Cl}_{3} \mathrm{NO}_{5} \mathrm{Si}$ : C, 43.92; H, 6.94; N, 3.01. Found: C, 43.72; H, 6.91; N, 2.94.

\section{Acknowledgements}

This work was partly supported by the Grant-in-Aids from the Ministry of Education, Culture, Sports, Science and Technology, Japan and the Japan Society for the Promotion of Science.

\section{References}

1. (a) Bewley, C. A.; Debitus, C.; Faulkner, D. J. J. Am. Chem. Soc. 1994, 116, 7631. (b) Faulkner, D. J.; Schmidt, E. W. Tetrahedron 1998, 54, 3043. (c) Qureshi, A.; Colin, P.; Faulkner, D. J. Tetrahedron 2000, 56, 3679.

2. For a recent review, see Shioiri, T.; Hamada, Y. Synlett 2001, 184.

3. (a) Sasaki, S.; Hamada, Y.; Shioiri, T. Tetrahedron Lett. 1997, 38, 3013. (b) Sasaki, S.; Hamada, Y.; Shioiri, T. Peptide Science- Present and Future, ed. by Shimonishi, Y., Kluwer Academic Pub., Amsterdam, pp 536-537. (c) Sasaki, S.; Hamada, Y.; Shioiri, T. Peptide Science 1998, ed. by Kondoh, Protein Reseach Foundation, Osaka, pp 17-20. (d) Sasaki, S.; Hamada, Y.; Shioiri, T. Synlett 1999, 453. (e) Sasaki, S.; Hamada, Y.; Shioiri, T. Tetrahedron Lett. 1999, 40, 3187.

4. (a) Yamada, S.; Oguri, T.; Shioiri, T. J. Chem. Soc., Chem. Commun. 1976, 136. (b) Oguri, T.; Kawai, N.; Shioiri, T.; Yamada, S. Chem. Pharm. Bull. 1978, 26, 803. (c) Irako, N.; Hamada, Y.; 
Shioiri, T. Tetrahedron 1995, 51, 12731. (d) Matsumoto, T.; Shioiri, T.; Osawa, E. Tetrahedron 1996, 52, 5961. (e) Matsumoto, T.; Shioiri, T.; Osawa, E. Tetrahedron 1996, 52, 5971. (f) Sugiyama, H.; Yokokawa, F.; Shioiri, T.; Katagiri, N.; Oda, O.; Ogawa, H. Tetrahedron Lett. 1999, 40, 2569. (g) Yokokawa, F.; Sugiyama, H.; Shioiri. T.; Katagiri, N.; Oda, O.; Ogawa, H. Tetrahedron 2001, 57, 4759-4766.

5. Ramalingam, K.; Woodward, R. W. J. Org. Chem. 1988, 53, 1900.

6. Ramsamy, K.; Olsen, R. K.; Emery, T. Synthesis 1982, 42. See also: Shioiri, T.; Irako, N.; Sakakibara, S.; Matsuura, F.; Hamada, Y. Heterocycles 1997, 44, 519.

7. Cf. Brooks, P. W.; Lu, L. D.-L.; Masamune, S. Angew. Chem. Int. Ed. Engl. 1979, 18, 72.

8. The configurations of 3a and its epimer epi-3a were determined by NOE experiments of their NMR spectra.

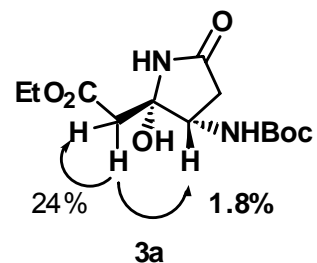

$3 a$

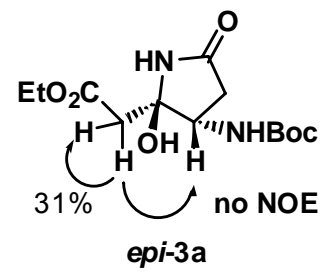

epi-3a

9. (a) Soderquist, J. A.; Thompson, K. L. J. Organomet. Chem. 1978, 159, 237-249. (b) Hamada, Y.; Kondo, Y.; Shibata, M.; Shioiri, T. J. Am. Chem. Soc. 1989, 111, 669.

10. Treatment of $\mathbf{2 4}$ under alkaline conditions followed by relactonization with EDC afforded the required $\mathrm{Y}$-lactone carboxylic acid $\mathbf{3 b}$.

11. Saito, S.; Ichikawa, T.; Kubota, A.; Koga, K.; Moriwake, T. Tetrahedron 1992, 48, 4067.

12. Deng, J.; Hamada, Y.; Shioiri, T. Synthesis 1998, 627. 